\title{
DA EXTREMA TRANSPARÊNCIA À SUTIL INVISIBILIDADE: O ESPAÇO DO NEGRO NAS EFÍGIES DOS MANUAIS ESCOLARES
}

\author{
Maria Aparecida Dias Castro ${ }^{1}$ \\ Antonieta Miguel $^{2}$
}

\section{Resumo}

Propõe-se, neste artigo, analisar imagens da África, de negros e afrodescendentes em quatro coleções didáticas para o Ensino Fundamental I, adotadas para as escolas públicas de Caetité, entre o período de 2010 a 2018, à luz de alguns pressupostos da Teoria das Representações Sociais (TRS) na perspectiva de Moscovici (1978, 2015), estudioso que alerta para a impossibilidade de compreender o indivíduo sem considerá-lo historicamente sujeito de uma construção cultural, política e econômica. No processo de análise de dados, foi possível constatar que as imagens que representam esse espaço e sujeitos sociais oscilam entre as que evidenciam uma preocupação em ser socialmente aceitáveis e aquelas que fugazmente desvelam construções históricas estereotipadas. É especialmente destas últimas que este texto se acerca.

Palavras-chave: Imagens. Teoria da Representação Social. História e Cultura Africana e Afro-brasileira.

\section{Abstract}

It is proposed, in this article, to analyze images of Africa, blacks and afro-descendants in four didactical collections for fundamental teaching I, adopted for public schools in Caetité between 2010 up to 2018 in light of some assumptions of the Theory of Social Representations (TRS) in the perspective of Moscovici (1978, 2015), a scholar who alerts for the impossibly to understand the individual without considering him historically a subject of a cultural political and economic construction. In the process of data analysis, it was possible to verify that the images that represent this space and social subjects, oscillate between the ones which show a concern in being socially acceptable quail between the ones which show a concern in being socially acceptable, and the ones which briefly reveal stereotypical historical constructions. This text is specially based on these last ones.

Keywords: Images, Theory of Social Representation. African and Afro-Brazilian History and Culture.

1 Professora da Rede Municipal de Ensino de Caetité e pós-graduanda Lato Sensu em Educação e Relações Étnicoraciais da Universidade do Estado da Bahia, Campus VI. Email: maria_dias8@live.com.

2 Orientadora. Graduada em Licenciatura Plena em História pela Universidade Estadual do Sudoeste da Bahia, especialista em História do Brasil pela Pontifícia Universidade Católica de Minas Gerais e mestre em História pela Universidade Federal da Bahia. Atualmente é professora assistente da Universidade do Estado da Bahia - Campus VI, atuando na graduação e pós-graduação. Compõe a Comissão Departamental de Estágio do Departamento de Ciências Humanas. Coordena o Projeto Interdepartamental Memórias da Educação. Disponível: $<$ http:/buscatextual.cnpq.br/buscatextual/busca.do $>$. Acesso: 05/05/2017. antonietamiguel40@yahoo.com.br. 


\section{Introdução}

Imagens $^{3}$. De tudo o que mais salta aos olhos nos livros didáticos, e possivelmente a priori, desperta a atenção dos pequenos leitores em formação, são as efígies que eles trazem, que não se circunscrevem ao aspecto estético-visual, se expandem, exemplificam, problematizam informações e, para além disso, são textos a dividir espaço com a escrita. Assim, elas jamais deverão vir de forma aleatória e incoerente com o conteúdo abordado. Elas têm de ser adequadamente selecionadas e dispostas para ampliar, aguçar a percepção do leitor, transcendendo o texto escrito, provocando novas possibilidades de construção do conhecimento.

As imagens são signos. Signos representam algo que requer ser lido e interpretado, uma vez que ajuda a construir sentidos para aquilo que se observa. Não obstante, deve-se compreender e reconhecer que "um elemento de uma imagem não significa que estamos compreendendo e decodificando, pois é inerente ao ser humano trabalhar com formas simbólicas” (TERRA, 2017). Portanto, ora velam, ora desvelam intencionalidades. Nessa perspectiva, as contribuições da Semiótica $^{4}$, são interessantes e podem ser aplicadas na apreensão de todas as formas de linguagem.

Ainda de acordo com Santaella (1983), o signo é algo que, mesmo falsamente, representa outra coisa. Se o signo é o indício de uma falta, compreende-se que é necessária a presença de decodificantes convencionados e socialmente aceitos para que sejam compreendidos em uma determinada coletividade. Situação explicada com irrefutável propriedade por Geertz (1973), ao tentar apreender os significados de uma piscadela. "É justamente uma explicação que eu procuro, ao construir expressões sociais enigmáticas na sua superfície" (GEERTZ, 1973, p. 15). Sendo assim, um fenômeno só pode ser compreendido à medida que se busca pictografar o universo em que ele foi forjado e, muitas vezes, repetido.

As imagens estão inseridas no domínio da cultura e, para serem decifradas, precisam,

3 Neste texto, os termos imagem, gravura, efígie, pictografia e ilustração, a despeito de algumas especificidades, foram empregados como sinônimos.

4 Desenvolvida por Charles Sanders Peirce, 1839, em Cambridge, Massachussets, nos EUA. Filho do matemático, físico e astrônomo Benjamin Peirce, sendo considerado um dos mais profundos e originais pensadores norteamericanos. Peirce deixou contribuições em múltiplas áreas do conhecimento, como Lógica, Semiótica, Astronomia, Geodésia, Matemática, Teoria e História da Ciência, Econometria e Psicologia. Disponível em:< https://educacao.uol.com.br/biografias/charles-sanders-peirce.htm>. Acesso: 14 fev. 2017. 
portanto, ser pensadas, independentemente da intencionalidade com que foram produzidas, como uma construção cultural individual e coletiva. Nesse esteio, uma possibilidade para repensá-las é ter como aporte a Teoria das Representações Sociais (TRS). Há estudos interessantes na educação que têm se embasado nessa teoria. No tocante aos livros didáticos, preferencialmente, faz-se menção ao trabalho de Silva (2011): A Representação Social do Negro no Livro Didático: O que Mudou? Por que Mudou?.

\section{1 - Teoria da Representação Social: possibilidades da apreensão de imagens nos livros didáticos}

A Teoria da Representação Social foi desenvolvida pelo psicólogo romeno Serge Moscovici, a partir do conceito de representação coletiva de Émile Durkheim.

A representação social pode ser compreendida como "um tipo de conhecimento que tem por objetivo a elaboração de comportamentos e a comunicação entre indivíduos" (MOSCOVICI, 1978, p. 26). Dessa forma, as representações sociais dizem respeito a uma gama de explicações, ideias e pensamentos que permitem remeter a um determinado objeto, fenômeno ou indivíduo, sendo resultado do processo de interação social.

Um dos aspectos a ser enfatizado na Teoria da Representação Social moscoviciana diz respeito à forte conexão entre as dimensões Indivíduo e Sociedade - por isso, a representação social deve ser apreendida "tanto na medida em que ela possui uma contextura psicológica autônoma como na medida em que é própria de nossa sociedade e de nossa cultura”. (MOSCOVICI, 1978, p. 45). Destarte, nas falas do autor, ainda é possível se apreender que, apesar de não ser um fenômeno de fácil definição, a representação social é, ainda, "alternativamente, o sinal e a reprodução de um objeto socialmente valorizado" (MOSCOVICI, 1978, p. 27).

Este teórico, inclusive, chama a atenção para a permanência de muitas representações, às vezes, de tempos imemoriais, mas que são reproduzidas e ressignificadas no cotidiano dos sujeitos sociais, o que reporta à ideia geertziana de cultura como uma teia de significados tecida pelos homens e por eles absorvida ao longo do tempo.

Outro autor a trazer contribuições pertinentes para repensar a Teoria da Representação 
Social é Abric (1994 apud CRUSOÉ, 2004) um dos responsáveis por um dos desdobramentos da TRS moscoviciana ${ }^{5}$. Ele especifica algumas funções das representações sociais: funções de saber, de identidade, de orientação e justificação das condutas. A função de saber das representações possibilita aos sujeitos compreender e explicar uma determinada realidade, em consonância com o funcionamento do seu sistema cognitivo e com seus valores e crenças. A função de identidade da representação funciona como uma proteção à especificidade dos grupos na medida em que situam os indivíduos ou grupos no campo social.

Ainda de acordo com Abric (1994 apud CRUSOÉ, 2004), a representação como orientação se presta a ser como guia de comportamentos e práticas. A função justificadora da representação atua para justificar os comportamentos e tomadas de posição dos grupos e indivíduos numa ação ou com relação aos seus parceiros. Estratégias essas que, como se verá, foram apreendidas nas efígies encontradas nos manuais escolares contemplados nesta pesquisa ${ }^{6}$.

O conceito de Representação Social também atingiu outros domínios do saber. Outra perspectiva de se pensá-la é pelo viés da História Cultural, sobretudo nos trabalhos desenvolvidos por Burke (2008), para quem a realidade é uma construção social e cultural, e Chartier (1990), que, por sua vez, amplia essa percepção ao compreender que as percepções do mundo social são impregnadas de intencionalidades; portanto, não se configuram como discursos neutros. Elas produzem estratégias e práticas que prescrevem infligir certa autoridade sobre outros.

A partir do exposto acima, as imagens podem ser pensadas como uma tênue linha a compor a complexa esfera da cultura, num campo onde as respostas nunca serão acabadas, mas um permanente vir a ser, coerente com a percepção de provisoriedade do conhecimento. Independentemente dessa complexidade, o que não se ignora é que, de acordo com Moscovici

5 A Teoria das Representações Sociais se difundiu no meio acadêmico e desdobrou-se em pelo menos três abordagens. A primeira dá seguimento a obra original, com um viés antropológico mais difundido por Denise Jodelet (2001). A segunda, através de Willem Doise (1990), se atém às condições de produção e circulação das representações sociais. A terceira é representada por Jean Claude Abric (1998), que dá ênfase à dimensão cognitivoestrutural conhecida como Teoria do Núcleo Central (MACHADO, ANICETO, 2010, p. 352).

6 Os livros adotados pela Rede Municipal de Ensino de Caetité, BA, cidade a aproximadamente 700km de Salvador, analisados nesta pesquisa, foram entregues nas escolas e utilizados por professores e alunos das 23 instituições que compõem a Rede Municipal de Ensino. O processo de escolha dos livros didáticos ocorre da seguinte forma: em reunião, os professores, por disciplina, indicam algumas coleções - uma preferencial, seguido de duas outras opções. Entretanto, observam-se falhas no processo de seleção dos manuais, particularmente por não considerar as especificidades históricas e culturais dos indivíduos que os receberam. Dessas escolas, por exemplo, quatorze se encontram na Zona Rural e nove no distrito-sede. Muitas delas, em particular as da Zona Rural, se fazem presentes em Comunidades Remanescentes de Quilombos. Ressalta-se, ainda, que esta pesquisa se encaminhou para a análise do livro em si. Usos e apropriações que os professores da Rede fazem desses materiais requerem outras investigações, pois há, nesse local, carência de estudos nesse sentido. 
(1978), a representação tem que ser compartilhada e elaborada por um determinado grupo e, dessa forma, ganhará “vivacidade" e atingirá as intenções para as quais foram forjadas.

\section{2 - Representação social de negros e afrodescendentes nos manuais escolares: primeiras impressões}

O primeiro decênio do século XXI brindou a sociedade brasileira com um cenário favorável as políticas de inclusão de afrodescendentes e de visibilização da cultura e história de matriz africana a partir de um aparato legal ${ }^{7}$, em resposta a séculos de resistência e reivindicação, particularmente do povo negro, por uma sociedade em que a equidade social seja a norma. Nesse esteio, é que a história da África e da diáspora e suas representações têm galgado maior espaço nos manuais didáticos produzidos. Por conseguinte, deitar o olhar sobre elas é prerrogativa para modificar a práxis pedagógica, contribuindo para uma aprendizagem significativa das relações étnico-raciais.

Atentando-nos para as imagens sobre a temática africana, como os estudos de Silva (2011), observamos que têm ocorrido alterações significativas na representação de africanos e afrodescendentes nos livros didáticos, quando comparados aos livros produzidos na década de 80 do século passado, "no que tange à sua humanidade, cidadania, territorialidade, status socioeconômico e integração com outras raças/etnias" (SILVA, 2011 p. 12), embora esses livros ainda representem uma minoria. Outra inovação percebida é a assimilação do negro ao branco, social e culturalmente. As considerações tecidas pela autora possibilitaram perceber que esse quadro não foi diferente nos livros das coleções observadas nesta pesquisa, havendo representações positivas de negros e afrodescendentes nos manuais, como é notório na imagem a seguir:

7 Trata-se da Lei 10.639 de 2003, como já visto instituiu a obrigatoriedade do ensino e cultura africana nos sistemas de ensino. Também a Lei 12.288 de 20 de julho de 2010 que instituiu o Estatuto de Igualdade Racial. 
Figura 1 - Ilustração do texto: Comunidade, memória e história

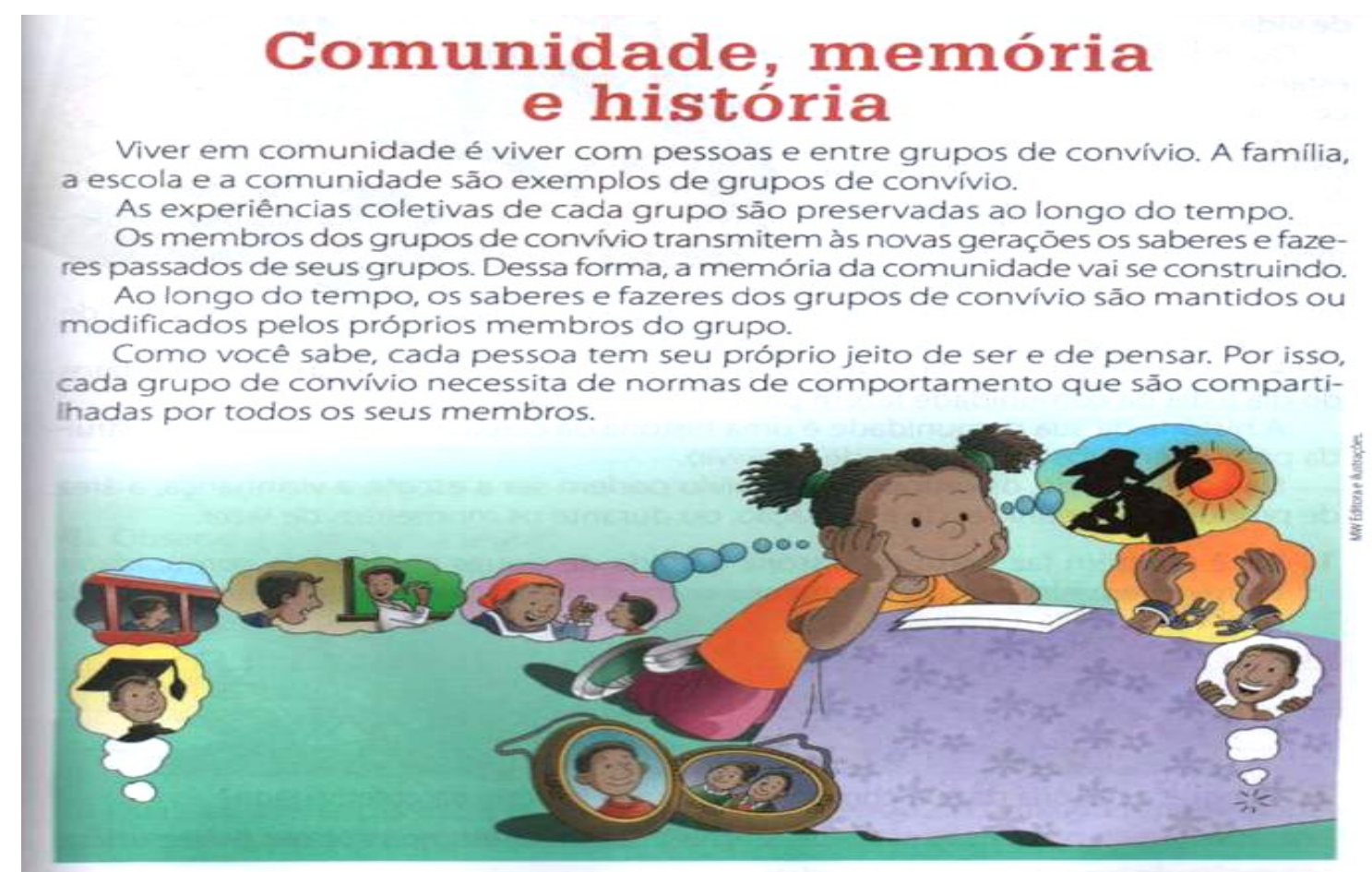

Fonte: História Novo Girassol, $4^{\circ}$ ano (2016/2018, p. 147).

A imagem denota uma harmonia e satisfação da criança em destaque, seja pela ancestralidade, seja pela perspectiva de um futuro melhor. A princípio, é importante considerar o que os elementos dispostos no contexto aludem, pois as trajetórias de vida encadeadas galgam melhores condições de sobrevivência, tendo na imagem do formando o desfecho. Não obstante, como sugere Terra (2017), é o repertório visual e cultural de cada indivíduo que permite diferentes olhares, inferências da realidade experimentada e a ser decodificada.

Observando detidamente, a menina reporta com visível satisfação para o seu passado; podese pensar que a imagem mais sugere orgulho e valorização de sua ancestralidade do que revolta pela escravidão. Assim, é possível apreender a contemplação pelas lutas que os seus antepassados empreenderam para se libertar e vislumbrar as muitas lutas que deverão se desenvolver para alcançar uma vida digna, pois o espaço onde ela está inserida se encontra praticamente vazio, carente, apenas preenchido por suas memórias e expectativas.

Segundo Bittencourt (2015), que fez um percurso sobre a inserção de imagens nos livros didáticos de História, as imagens têm sido um importante recurso pedagógico, usado há mais de um século por autores e editores dos manuais escolares de História. Assim sendo, percebe-se que nem 
sempre esses recursos transparecem, à primeira vista, suas intencionalidades, ao serem selecionadas e dispostas nesses suportes. Um aspecto positivo dos suportes didáticos refere-se à apresentação das nuances da tez da população brasileira. De um modo geral, têm sido exímios em demonstrar as suas diversas gradações, em particular a afrodescendente, proporcionando aos estudantes verem a si e ao próximo nas muitas realidades representadas nos manuais.

\section{Figura 2- Gradações da cor negra na população brasileira}
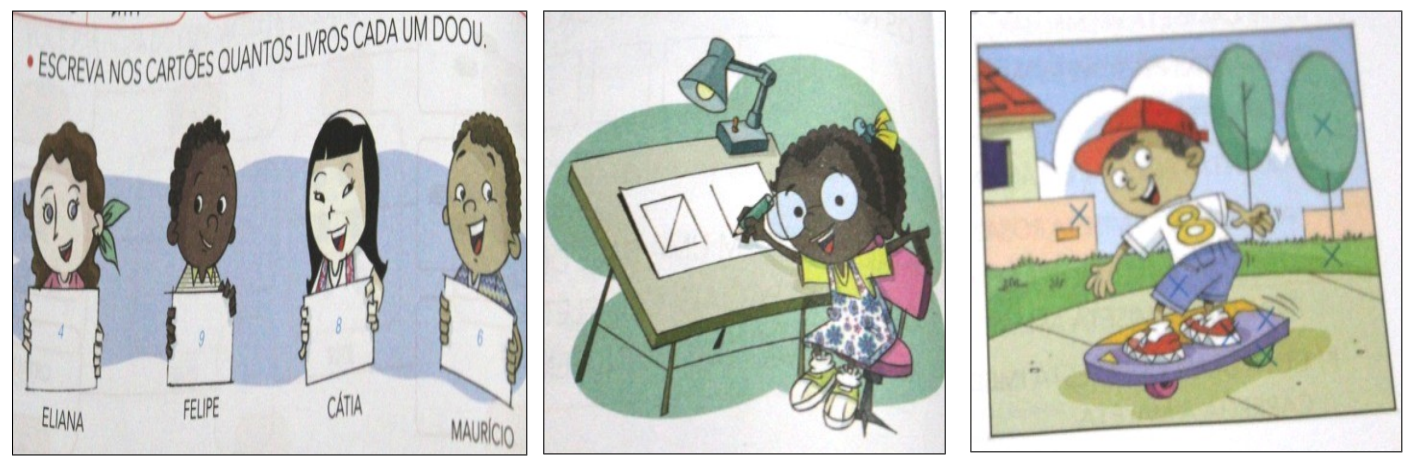

Fonte: Matemática Ápis, $2^{\circ}$ ano (2016/2018, p. 18, 20 e 21).

Esta representação reflete as mesclas biológicas ocorridas no Brasil desde a colonização. Por diversas vezes, traços fenótipos distintos são observados nos indivíduos representados. Dessa maneira, demonstrando para o jovem leitor "as diversas faces" que compõem o nosso País. Além disso, são dispostas compartilhando o mesmo status social, econômico e cultural - o que, se por um lado, positivamente atribui equivalência a todos, por outro, deixa a desejar no tocante à reflexão sobre as diferenças e contradições culturais, que, como se verá, são sutilmente invisibilizadas.

Outra preocupação comum nos manuais didáticos diz respeito a algumas circunstâncias em que brancos estão prestando serviços aos negros. Dessa forma, têm sido usuais as situações em que os negros e afrodescendentes demonstram poder de compra, sendo atendidos por indivíduos de fenótipo branco, em condições que anteriormente se representava apenas o seu inverso.

Essa inversão de situações sociais, geralmente, apresenta indivíduos com status econômico mediano, ou seja, pessoas que mantêm um padrão de vida razoável, que conseguem sobreviver com o básico. Esta situação, apesar de refletir a condição econômica e social de parte expressiva da população brasileira, por outra perspectiva, pode estar sutilmente sugerindo para as populações afro-brasileiras os marcos sociais e econômicos aonde elas podem chegar. 


\section{Figura 3 - Troca de lugares sociais}
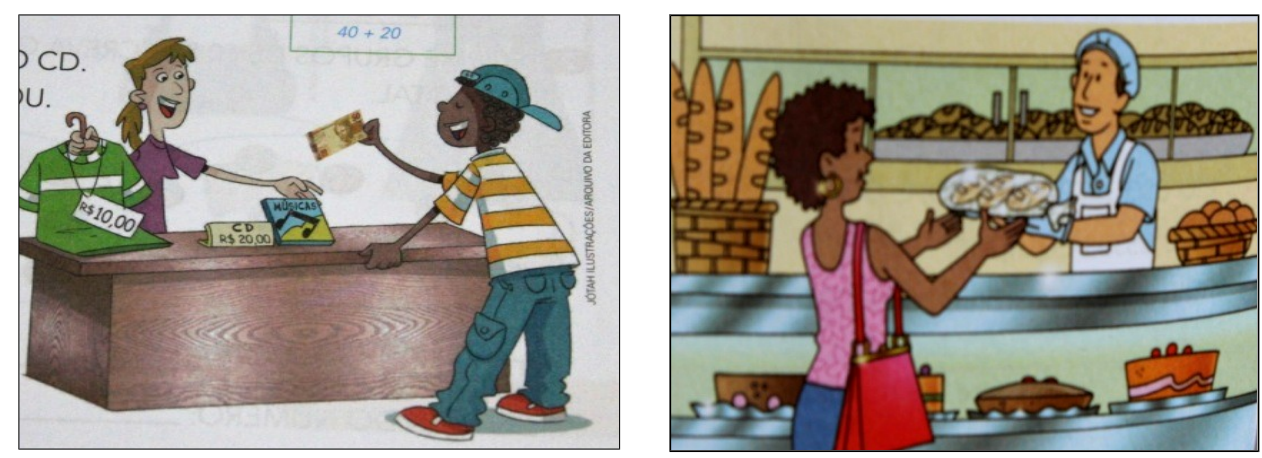

Fontes: Matemática Ápis, $2^{\circ}$ ano (2016/2018, p. 73) e A Conquista da Matemática, $\quad 2^{\circ}$ ano $(2013 / 2015$, p. 214).

Nestas imagens, o diferencial é os negros demonstrarem status econômico e o ambiente de cordialidade inter-étnica. Estas ilustrações apresentam um aspecto positivo, sobretudo para as crianças negras, que certamente se sentem inseridas nessas situações. Destacam-se, também, as profissões que requerem maior nível de instrução. Nestas, sim, os afrodescendentes são mais visualizados, inclusive, servindo de referência positiva quanto à inserção social e profissional.

Figura 4 - Os negros ascendem no mercado de trabalho
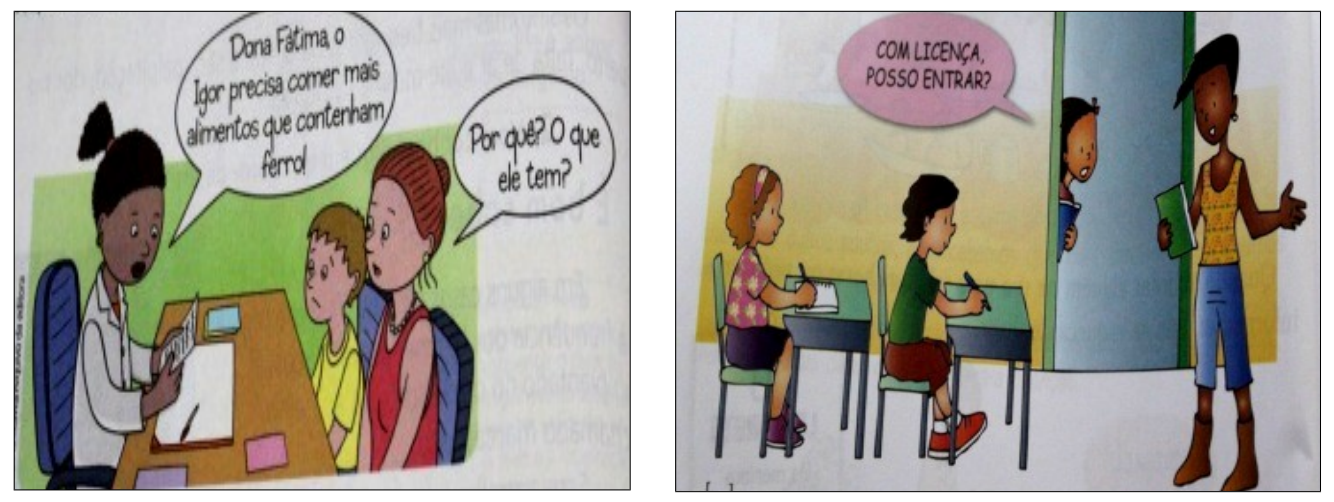

Fontes: Português Porta Aberta, $3^{\circ}$ ano (2013/2015, p. 12) e Ciências A Escola é Nossa, $5^{\circ}$ ano (2010/2012, p. $36)$.

É certo que o oposto dessas imagens positivas também aparece, ainda que em menor quantidade. De um modo geral, esses livros têm se esquivado em apresentar, em suas imagens, situações degradantes e subalternas das pessoas negras na atualidade. São corriqueiras as que tematizam a escravidão, sobretudo nos livros didáticos da disciplina de História. 
Cavaleiro (1998) e Gomes (2005) também destacam que a escola, apesar do caráter democrático que tem se revestido, de espaço de reconhecimento social e de inclusão, é uma das instâncias em que as representações pejorativas dos negros são difundidas. Pode-se, dessa maneira, inferir que essa cautela é oriunda do receio às críticas contundentes das representações desses sujeitos, o que poderia inviabilizar a venda desses manuais, pois, como Bittencourt (2015) ainda sustenta, a problemática da ilustração dos livros está relacionada ao contexto mercadológico e técnico, em que a história do livro didático sugere como os autores paulatinamente foram perdendo o poder sobre a ilustração de suas obras.

\section{3 - Detendo o olhar sobre as efígies dos manuais escolares: a permanência de estereótipos}

À primeira vista, é indiscutível que os manuais têm procurado enaltecer, em sua representação imagética, sujeitos sociais de compleição diversificada. Sendo assim, a população brasileira (com nítida ascendência africana) se faz inserida nesses livros, mesmo que quantitativa e qualitativamente limitada, está mais condizente com as discussões sobre as relações raciais na contemporaneidade. Não obstante, não se procura o óbvio, e, sim, o evidente - porém, não subjacente. Evidências do que circunscreve a representação social desses indivíduos, sugestivamente expressas em sutilizas, que sem se deter o olhar com atenção podem passar despercebidas. Este é o exemplo da imagem desenhada abaixo.

\section{Figura 5 - $O$ vendedor de algodão-doce}

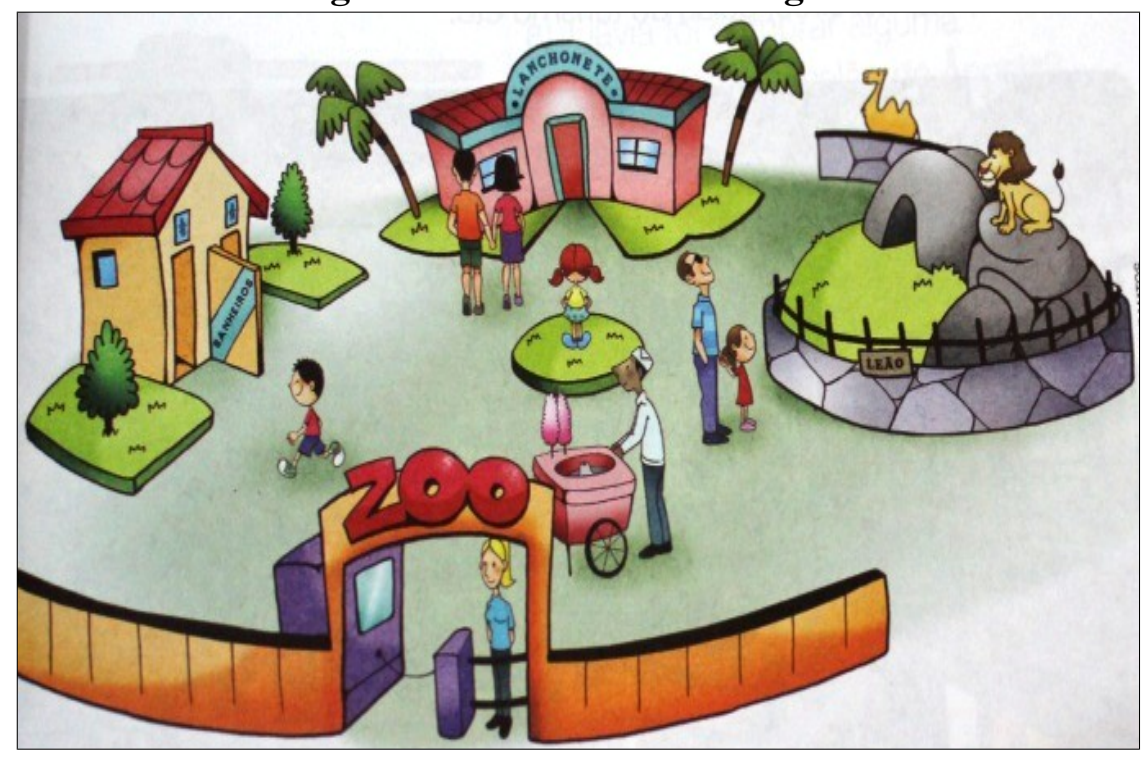

Fonte: Geografia Projeto Buriti, $2^{\circ}$ ano $(2013 / 2015$, p. 65$)$. 
Chama a atenção na imagem o fato de todos os que estão se divertindo no zoológico serem brancos, enquanto o vendedor de algodão-doce é o único negro a compor o cenário. Os livros didáticos ainda teimam em reproduzir a ideia de lugar reservado ao negro como de prestador de serviço para uma minoria branca, elitista, a quem o ócio pode ser reservado. Dessa forma, considera-se o livro didático, ainda que relevante, um objeto suspeito e sujeito a várias leituras.

$\mathrm{Na}$ ilustração acima, a mulher, na entrada do zoológico, por sua postura, pode ser interpretada ora como funcionária que, à primeira vista, acolhe os visitantes, guarda o local ou exerce função de nível mais elevado, ora como mais uma visitante que parou para observar o entorno. Entretanto, ao contrário do vendedor, é mais difícil associá-la ao trabalho.

O enquadramento do negro, tanto quanto do branco e do indígena, em determinados espaços e situações, sem transparecer uma intencionalidade racista, grosso modo, é possível por uma série de sutilezas e meandros, nem sempre perceptível, verificadas apenas por um olhar cuidadoso. Sob esse ponto de vista, não são incomuns as imagens como narrativas em que atribuem aos indígenas o status de algo passado, extinto, de presente apenas no começo da história do Brasil - daí a ênfase quase exclusiva na mitologia desses povos. Como do negro frequentemente associado à escravidão, e do branco como o principal agente da história.

Ao debruçar o olhar sobre as efígies constantes nos manuais escolares, contemplados nesta pesquisa, foi, ainda, possível se constatar uma perversa associação do negro ao escravo ou a elementos que remetem à escravidão. Na figura 6 abaixo, na primeira imagem, da esquerda para a direita, apresenta-se um cartaz de campanha lançada no ano de 2012 pela Organização Internacional do Trabalho (OIT) contra o trabalho escravo e o trabalho infantil no Brasil, Geografia Ligados.com, $4^{\circ}$ ano $(2016 / 2018$, p. 85).

Dessa forma, apresenta-se quem está condicionado "naturalmente" a ser assujeitado à condição de escravo. A imagem perpassa uma ideia de continuidade da escravidão, e ainda pode sugerir que o trabalho escravo se dá exclusivamente no meio rural. Embora seja mais comum em latifúndios, também ocorre em fábricas na zona urbana, sobretudo ilegais, e no serviço doméstico persistindo, assim, o trabalho análogo ao da escravidão. 


\section{Figura 6 - Associação do negro ao escravo}
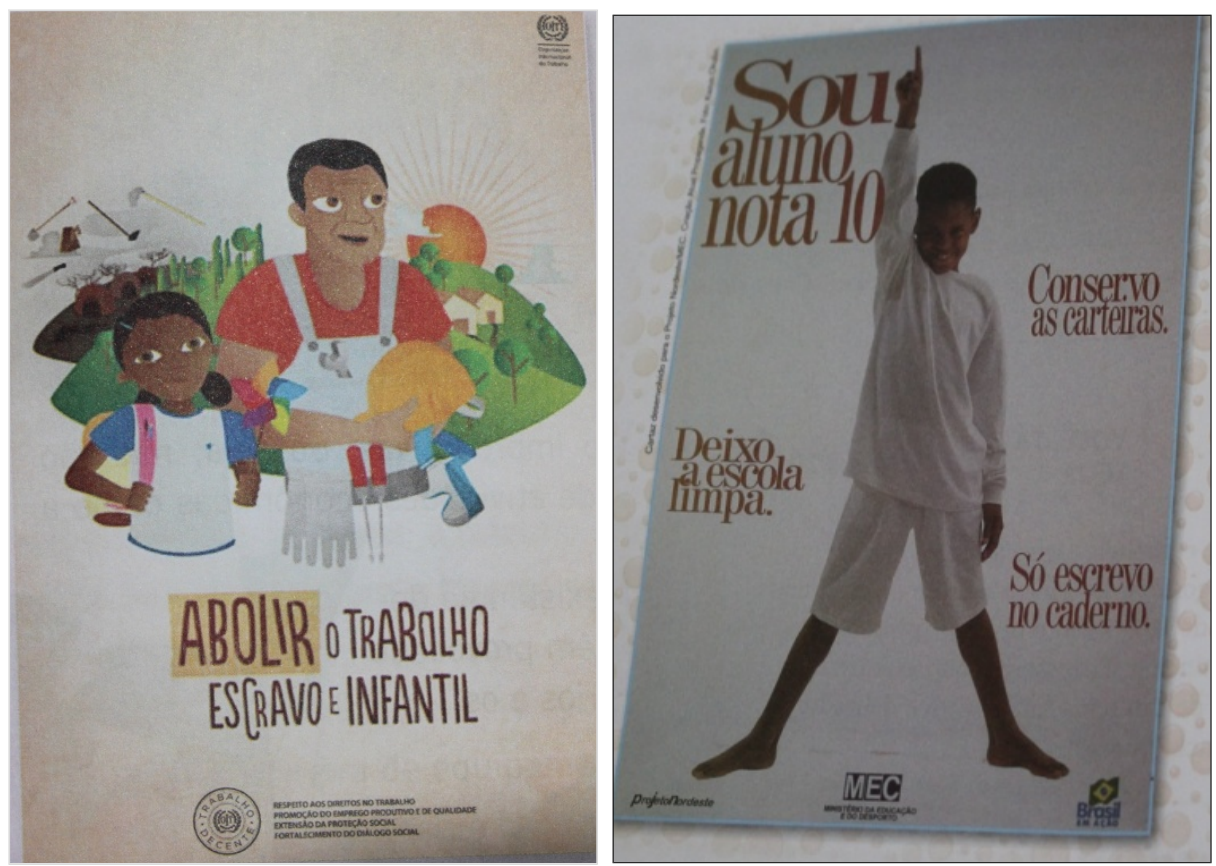

Fontes: Geografia Ligados.com, $4^{\circ}$ ano (2016/2018, p. 85) e Português Porta Aberta, $3^{\circ}$ ano $(2013 / 2015,2011$, p. 16).

Além do mais, o problema se agrava por não se produzir uma discussão sobre as relações étnico-raciais, considerando o público-alvo, contribuindo, assim, para a desconstrução da ideia transmitida pelas imagens, como se observa nas questões do livro Geografia Ligados.com, $4^{\circ}$ ano (2016/2018 p. 85), aqui transcritas: “A) Qual o objetivo do cartaz? B) Na sua opinião, por que a campanha divulgada no cartaz foi organizada?" E, “4. Você conhece alguém que trabalha (ou trabalhou) no meio rural?"

Na segunda imagem (Figura 6), de um cartaz de divulgação, publicado pelo Ministério da Educação e Cultura (MEC), são evidentes as vestimentas da criança; similares, pela simplicidade e pela cor, às roupas dos negros quando escravizados. Acrescente-se a isso o fato de a criança estar com os pés descalços ${ }^{8}$, reportando à imagem cristalizada dos negros subjugados pelo escravismo, tanto que, tão logo conquistavam a liberdade, os ex-escravos tinham como primeiro intento obter calçados. Igualmente, quando fugiam, passavam a usá-los estrategicamente para se passar por

8 No Brasil, o costume era que escravos andassem descalços, a fim de evidenciar diante da sociedade a sua condição servil. O costume não foi inventado na Colônia, mas vinha dos antigos romanos, para facilitar a distinção entre um homem livre de um escravo porque em Roma não havia a possibilidade, com raríssimas exceções, de estigmatizar escravos com base na cor da pele. Além disso, muitos escravos tinham origem social elevada, como os gregos derrotados em combate. Exceções a essa regra eram raríssimas no Brasil (IASEN, 2015). Disponível em $<$ https://martaiansen.blogspot.com.br/2015/02/escravos-que-usavam-sapatos.html>. Acesso: 15 mar. 2017. 
livres.

Outro agravante é que ao associar imagem e texto e a criança responder que deixa a escola limpa, remete à construção social dela - ou melhor, do negro como aquele responsável pela limpeza, ou seja, o de trabalhador doméstico. Assim, os lugares sociais vão sendo desenhados e reforçados nos manuais escolares. Apesar de não ser a regra geral, vai contra a assertiva de Silva (2011), quando pontuou nos manuais por ela analisados que essas imagens haviam sido suprimidas.

A representação da criança negra descrita e ilustrada como o filho da empregada, o moleque de rua, o trabalhador braçal, identificado nas pesquisas anteriores, cedeu lugar a uma criança também com direito ao lazer. (SILVA, 2011, p. 14).

Isso se torna mais evidente quando, logo na sequência das imagens discutidas acima (Figura 6), o livro didático insere ilustrações de estudantes brancos, com o perfil socialmente construído de estudantes. Nestas imagens, como se verá também na Figura 7 abaixo, materializam-se estereótipos, representações sociais dos sujeitos envolvidos e dos grupos que integram. Nelas, se reflete claramente algumas funções das representações sociais, seja a de identidade, orientação e justificadora, pois tanto guiam comportamentos como protegem as características de determinados grupos. O que se discute é que a relação imagens e textos pressupõe uma intencionalidade, principalmente quando estão relacionados a outras efígies que remetem ao lugar do branco e às posições sociais que convencionalmente lhe dizem respeito.

Figura 7 - O branco em situação de vantagem social

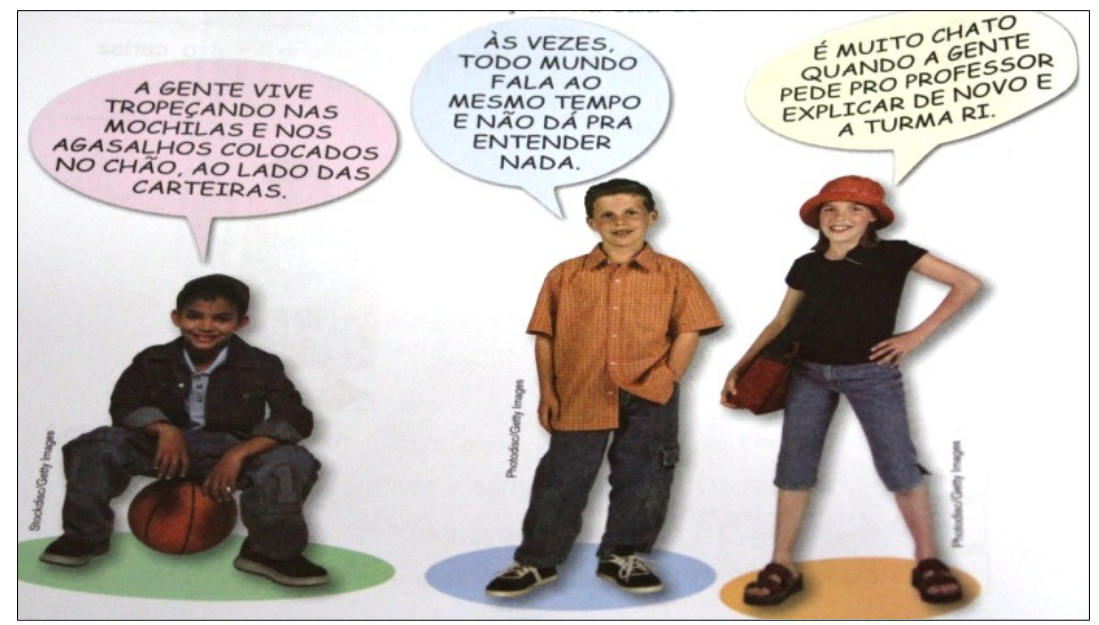

Fonte: Português Porta Aberta, $3^{\circ}$ ano (2013/2015, p. 17). 
Nas representações dos corpos negros, nos livros didáticos, por diversas vezes, ainda persistem estigmas históricos, apresentados de forma cômica, risível. Heranças da sociedade escravocrata, que ainda teimam em persistir, pois os estereótipos balizam a singularidade do outro, ao tempo em que estabelecem fronteiras entre o que Hall (1997) diferenciou de normal e o aceitável daquilo considerado anormal e inaceitável, quando procura manter a ordem social e simbólica da sociedade.

Segundo Rodrigues (2009), Nina Rodrigues ${ }^{9}$, apesar de mulato, não se percebia como tal e, por absorver conceitos eurocêntricos, em particular derivados do darwinismo social, defendia a ideia de que havia raças mais evoluídas do que outras - sendo a negra a mais inferior na linha evolutiva. Dessa forma, ela seria portadora de anomalias biológicas e sociais. Tanto assim que consideravam a presença negra como responsável por doenças infectocontagiosas, e que negros possuíam predisposição à criminalidade.

Para legitimar essa afirmação, os estudos do período estabeleciam uma ligação entre o formato do crânio e a pressão que esse formato exercia sobre o cérebro, condicionando o negro à criminalidade e à marginalidade. Por essas percepções, muitos estudiosos consideravam o negro uma raça inferior. [...] Dentro desta tendência, o negro passou a ser problema científico tratado pelas teorias do evolucionismo e da teoria da degenerescência. (RODRIGUES, 2009, p. 84).

A condição biológica do indivíduo africano e afrodescendente como anômala e inferiorizada ainda é passível de ser representada nos manuais didáticos. O primeiro aspecto a considerar é a curvatura dorsal que nem sempre se demonstra ereta, aproximando-os anatomicamente dos símios.

9 De acordo com Rodrigues (2009), tendo por base estudos da Biologia do século XIX, Nina Rodrigues ratificava o pensamento de que eles constituíam uma raça inferior. Entretanto, como ressalta Nascimento (2015), essa tese foi gradualmente se alterando com o desenvolvimento de estudos culturalistas, como o de Gilberto Freyre e os realizados pela Escola Sociológica da USP, críticos do mito da democracia racial, entre os anos de 1950 e 1960 , tendo Florestan Fernandes como um dos principais ícones. Destacam-se, ainda, os estudos culturais desenvolvidos por Stuart Hall, que considera a inexistência de essência racial, contribuindo decisivamente para a superação desse conceito biológico. A partir de então, raça passou a ser pensada numa perspectiva histórico-cultural. 
Figura 8 - Corpos negros, corpos estigmatizados
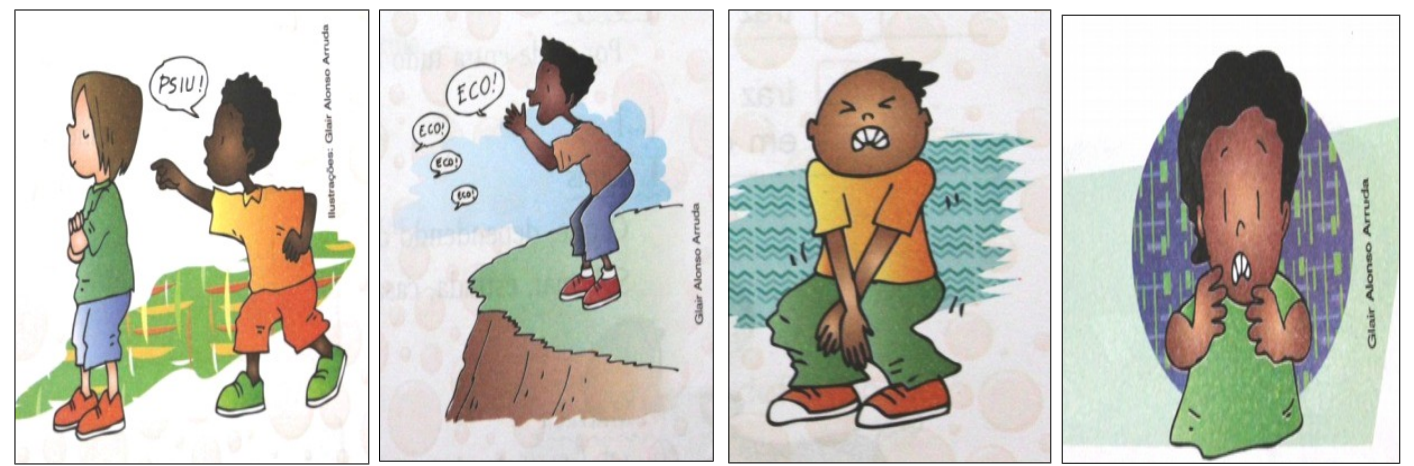

Fonte: Português Porta Aberta, $3^{\circ}$ ano (2013/2015, p. 33, 31 e 221).

A deformação na arcada dentária é outra representação social que beira o monstruoso, ao animalesco, e se repete principalmente no livro Português Porta Aberta (2013/2015), embora não seja a regra geral. Não foram verificados nos manuais consultados indivíduos brancos com a dentição deformada ou a postura encurvada; em geral, sua postura é ereta e altiva, sugerindo poder, liderança e autoestima elevada.

Outro exemplo que desvela a ênfase negativa sobre particularidades dos corpos negros refere-se à apresentação de personagens, sobretudo do futebol, que em alguns momentos também se apresentam nos livros didáticos. Tal é o caso de Dentucinho, caricatura do jogador Ronaldinho Gaúcho, personagem de Mauricio de Sousa, e do Pelezinho, do mesmo cartunista.

\section{Figura 9 - Personagens de Mauricio de Sousa}
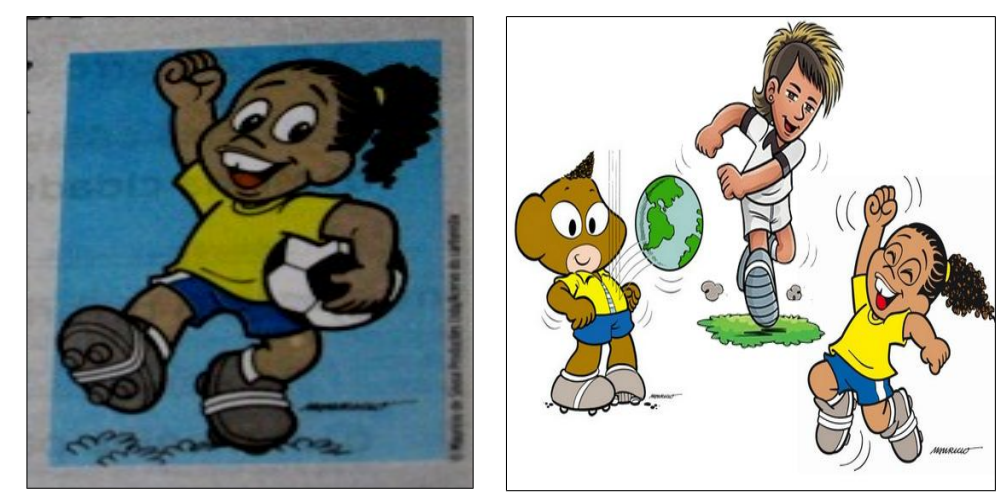

Fontes: Português A Escola é Nossa, $3^{\circ}$ ano (2010/2012, p. 73) e $<$ http://garciarama.blogspot.com.br/2014_09_01_archive.html>. Acesso: 26 nov. 2016.

Na segunda gravura, à direita, comparando-se as personagens, é significativo como o autor prima por reforçar uma ideia pejorativa do biótipo negro, e paripassu, não acentua comicamente 
nenhum aspecto do outro jogador de tez mais clara. Assim, entre formas harmônicas de representação desses sujeitos, as desproporcionais, vez ou outra, vão pincelando os textos numa constante e sutil busca de elos com expressões racistas, veiculadas na tessitura social, mas que não podem vir à tona de forma explícita nos manuais escolares.

Sobre esse aspecto é interessante a afirmação de Oliva (2007), quando se atém à materialização nos livros didáticos de representações sociais sobre esses sujeitos históricos.

[...]é quase certo que do passado - recente ou multissecular - e do presente nos chegam exemplos e reflexos de uma série de comportamentos e construções imagéticas que lançam os africanos e o seu continente para uma condição, muitas vezes, depreciativa. (OLIVA, 2007, p. 6).

Desse ponto de vista, a representação de Pelezinho foi a mais dramática. Possui diferenciação no formato dos olhos e da boca, circulada por uma tonalidade rosa igual à que possuía o personagem Jeremias antes de uma série de críticas que recebeu.

Assim, outras possibilidades de inserção desses sujeitos devem ser defendidas, como em algumas situações já sinalizadas nos manuais, mas precisam ser repensadas e ampliadas. É ainda nesse contexto que membros inferiores e superiores desproporcionais constituem-se em outro elemento racista agregado aos manuais didáticos.

\section{Figura 10 - Membros desproporcionais}
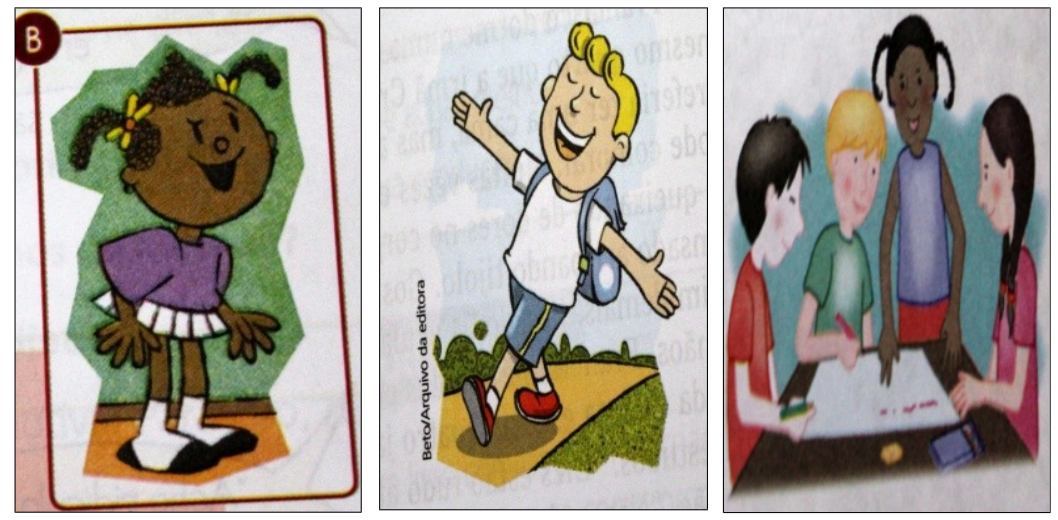

Fonte: Português A Escola é Nossa, $5^{\circ}$ ano (2010/2012, p. 81, 164 e 89).

A primeira menina possui a cabeça desproporcional e a curvatura acentuada. Os braços da 
criança negra estão mais alongados, comparando com as outras; apesar de estar na mesa estudando com elas, observa-se que é a única que está em pé e de forma sutilmente afastada das demais pictografia que, mais uma vez, remete ao lugar do trabalhador doméstico, que está a postos, à espera dos comandos daqueles que estão em situação de mando. Bem diferente do garoto disposto no centro.

As representações sociais desses indivíduos apontadas acima têm na ideia de raça africana um "elemento inevitável desse discurso" (APPIAH, 2014, p. 14). Esse autor, ainda, chama atenção para o fato de que essas noções se fundamentam em ideias biológicas e éticas extremamente precárias. Tais teorias raciais obtiveram pujança nos EUA e na Europa, sobretudo em fins do século XIX, tendo como característica preponderante a inferiorização dos negros.

Os estudos de Appiah (2014), ainda, apontam três doutrinas cruciais denominadas de racismo: o "racialismo", o "racismo extrínseco"10 e o "racismo intrínseco"11. O "racialismo" é o pressuposto de outras doutrinas chamadas de racismo, marcado pela perspectiva de que há características hereditárias, possuídas por membros de nossa espécie, possibilitando que sejam divididos em um pequeno conjunto de raças, onde os seus membros compartilham entre si determinados traços e tendências singulares, ou seja, que não têm em comum com membros de nenhuma outra classificação racial. Essas características específicas de uma raça, segundo a visão racialista, constituiriam "uma espécie de essência racial" e dizem respeito a mais do que as características morfológicas visíveis. Essa “essência racial” englobaria, também, aspectos culturais.

Para Appiah (2014), todas essas formas devem ser evitadas. Não obstante, acredita-se que a herança do "racialismo" 12 ainda se faça presente ao se construir arquétipos como esses vistos anteriormente. Assim, causa perplexidade que, com o campo de discussão aberto pelos estudos culturais sobre a temática, tais livros ainda incorram em reducionismos como os observados até então. Aliás, os corpos negros poderiam ser pensados na perspectiva de Antonacci (2013), como repositórios da ancestralidade dos povos africanos e, de tal modo, trabalhados no cotidiano escolar.

10 O "racismo extrínseco" seria fundamentado em "distinções morais entre os membros das diferentes raças". Tais racistas acreditam "que a essência racial implica certas qualidades moralmente relevantes".

11 O "racismo intrínseco" ocorre quando as pessoas "estabelecem diferenças morais entre os membros das diferentes raças"; acreditam "que cada raça tem um status moral diferente, independentemente das características partilhadas por seus membros".

12 [...] O conceito de "raça" não faz sentido senão no âmbito de uma ideologia ou teoria taxonômica, à qual chamarei de "racialismo". No seu emprego científico, não se trata de conceito que explique fenômenos ou fatos sociais de ordem institucional, mas de conceito que ajude o pesquisador a compreender certas ações subjetivamente intencionadas ou o sentido subjetivo que orienta certas ações sociais (GUIMARÃES, 1999, p. 19). 
Além disso, são representativos de relações de poder conflituosas. "O corpo é uma linguagem, e a cultura escolheu algumas de suas partes como principais veículos de comunicação. O cabelo é uma delas" (GOMES, 2003, p. 174). Instância da ancestralidade e identidade africana, aliás, das sociedades de um modo geral, o cabelo, ainda segundo Gomes (2003), está ligado diretamente à autoestima e à simbologia de cada cultura em particular.

Dessa forma, poderia ser trabalhado e valorizado especialmente nos livros escolares e no cotidiano pedagógico em situações as mais diversas possíveis, mas esta última esvai-se aos propósitos deste estudo. Como foi evidenciado no artigo anterior, houve uma única narrativa voltada para a afirmação da identidade negra a partir dos cabelos ${ }^{13}$. Há outros textos que poderiam tematizá-los, como O Cabelo de Lelê e As Tranças de Bintou ${ }^{14}$; afinal, o corpo negro está historicamente (e no presente) estigmatizado por uma gama de preconceitos, que o distingue das demais etnias e o restringe a determinados espaços.

Entretanto, as representações sociais de africanos e afrodescendentes não se reduzem à deformação corpórea. Há, ainda, uma forte associação do negro à falta de higiene. Como observado nas narrativas, também, é verificável na inserção de imagens. Nesse sentido, destaque-se, novamente, o Cascão. Ao observar os cabelos do garoto, é possível identificar uma ancestralidade africana. Obviamente, pressupõe-se que a criança, possuidora de cabelos crespos, terá este protagonista como referência e, como se denota na tirinha no centro (Figura11), ele é o responsável por "emporcalhar" os demais.

\section{Figura 11 - Representação do negro como o que não tem higiene}

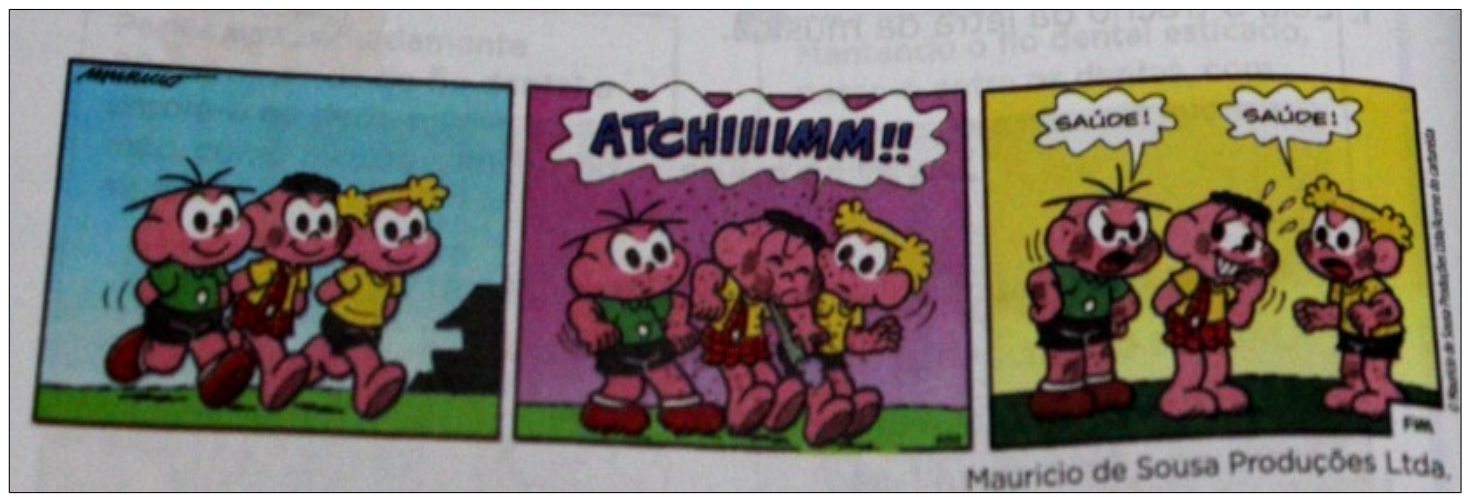

Fontes: Ciências $A$ Escola é Nossa, $2^{\circ}$ ano (2010/2012, p. 188)

13 Refere-se ao texto "Antes Menina Queria Ficar Careca". Português A Escola é Nossa, $2^{\circ}$ ano (2010/2012, p. 127128).

14 BELEM, Valéria. O Cabelo de Lelê. Ibep Nacional, 2012, também DIOUF, Sylviane A. As Tranças de Bintou. Cosac Naify, 2004. 
$\mathrm{Na}$ imagem abaixo, à esquerda, na ilustração da capa da revista, vê-se novamente o Cascão, que segue andando com os porquinhos. Fácil identificar se tratar da história Os Três Porquinhos, pela inserção do lobo e da casa no cenário. Sendo assim, ele pode ser naturalmente identificado como um dos irmãos dessa conhecida história. Além disso, a associação de Cascão aos porquinhos da história remete à desumanização do negro.

Figura 12 - Não só sujo, mas de humanidade duvidosa
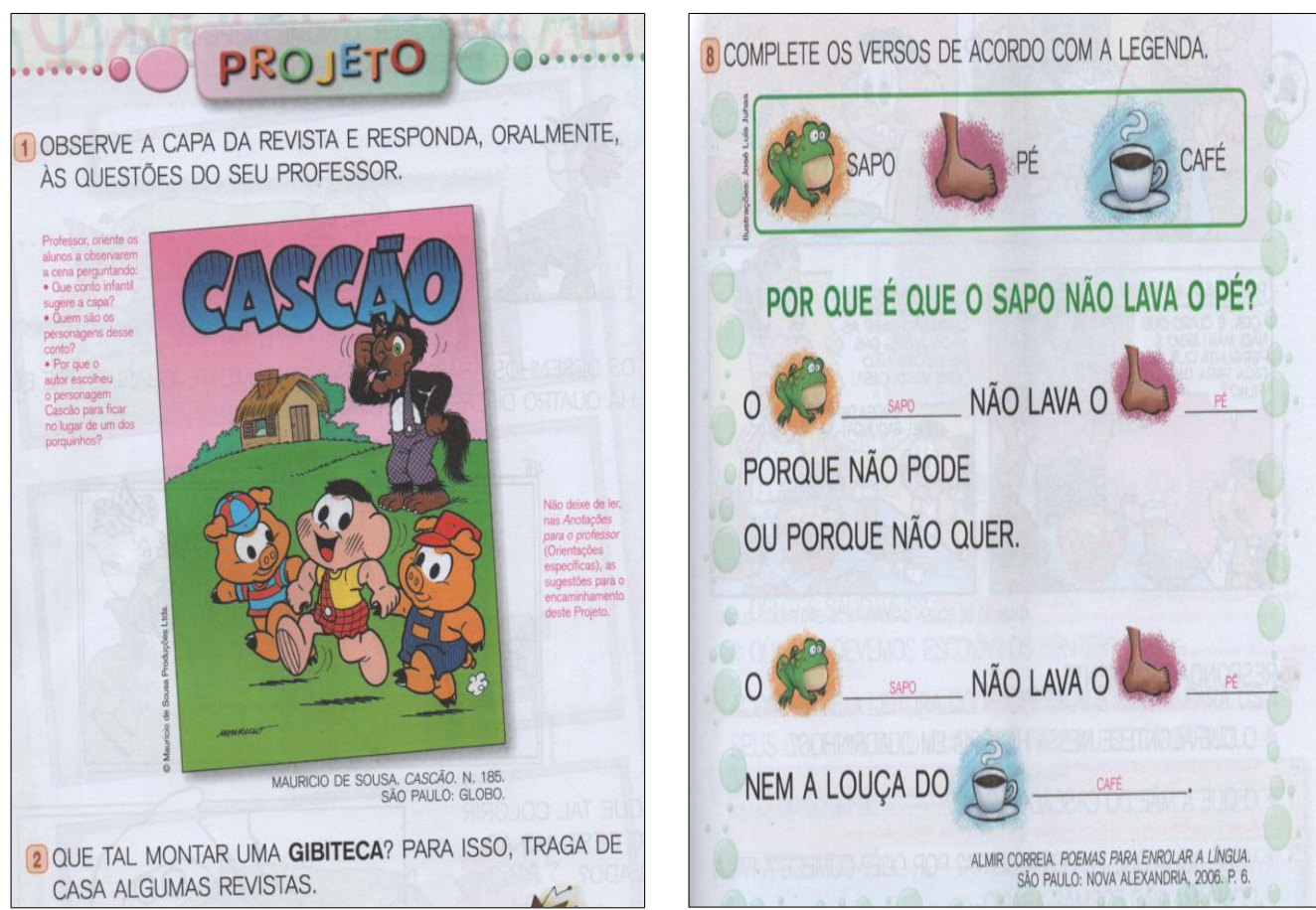

Fontes: Português Porta Aberta, $1^{\mathrm{o}}$ ano (2013/2015, p. 40 e 119).

Mais uma vez é notória a associação do negro à sujeira. Não deveriam ter representado o pé de um sapo? Por que um pé negro? Qual o motivo da associação? O negro, mais uma vez, vê-se associado ao animalesco e à sujeira. De um modo geral, são poucas as representações do negro, e não é incomum elas serem fontes de equívoco.

Não se verificou nesse livro nenhum texto que tematize as questões étnico-raciais. Nele, o preconceito não existe e não é problematizado. Não obstante, está posto com essa sensibilidade cruenta que lhe reserva os mesmos papéis sociais adquiridos na sociedade escravocrata, mas que ainda permeia o ideário social e está a orientar o trabalho dos autores e ilustradores dos livros didáticos.

Dessa forma, a representação do pé afro na imagem à direita (Figura 12) ainda se presta a 
discutir outra astúcia verificada nos livros didáticos. As mãos que orientam o desenvolvimento de atividades, salvo raríssimas exceções, como uma negra encontrada no livro Ciências $A k p a l o \hat{o}, 5^{\circ}$ ano (2016/2018, p. 15), são brancas; esta é a regra de representação de membros como mãos e olhos. Outro ponto que não fugiu à percepção e sinalizado na figura abaixo, é que em diversos momentos, em situação de interação entre brancos e negros, estes últimos aparecem distanciados ou ao fundo nas imagens.

Figura 13 - Beirando as margens
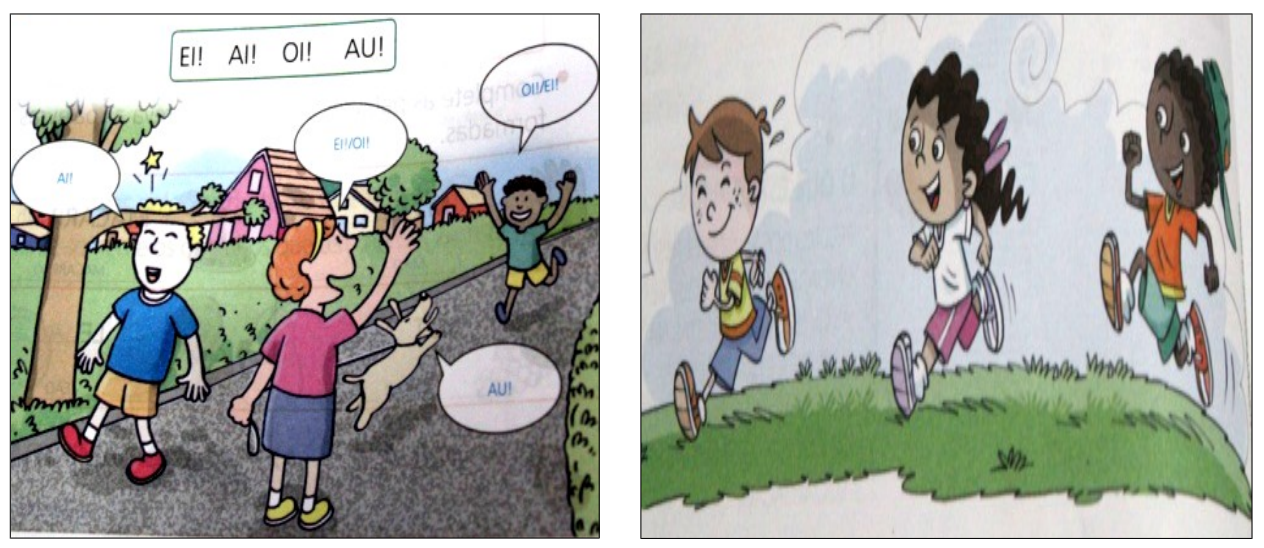

Fontes: Português $A$ Escola é Nossa, $1^{\circ}$ ano (2010/2012, p. 32) e Matemática Ápis, $2^{\circ}$ ano (2016/2018, p. 6).

A ideia constante de embranquecimento é outro aspecto a ser considerado nos livros didáticos, sendo mais comum a representação das famílias brancas e raríssimas as das famílias negras. O fato é que essa ideia do oitocentos, veiculada sobretudo por teóricos do Instituto Histórico e Geográfico Brasileiro (IHGB), ainda parece se impor.

De acordo com Guimarães (1988), tal instituição tinha como uma das suas principais atribuições construir a ideia de Nação brasileira perante as demais, particularmente as europeias, dando-lhe um papel de vanguarda na América, por ter sido a única a se emancipar do jugo colonial, preservando uma monarquia. No entanto, essa pretensão se esbarrava no caráter identitário do Brasil, marcado pela presença de diferentes grupos étnicos. A solução fomentada, segundo o projeto desenvolvido por esse Instituto, seria mediante a mescla desses indivíduos, e que, gradativamente, levaria ao embranquecimento populacional. Observa-se, assim, como nos livros didáticos esses conceitos transcendem o tempo e são reapropriados, à medida que deixam pouco espaço para famílias com biótipo negro estarem presentes nas cenas representadas, ao tempo em que valorizam as famílias brancas ou que gradativamente vão sofrendo o embranquecimento. 
Nos livros didáticos, algumas imagens reportam ainda mais a essa ideia, que predominou nos círculos eruditos brasileiros no século XIX. Num ambiente de construção do Estado Nacional, era imprescindível forjar uma identidade coletiva a partir de um projeto "historiográfico capaz de garantir uma identidade - especificidade à Nação em processo de construção”, que seria realizada a partir da "ideia da mescla das três raças, lançando os alicerces para a construção do nosso mito da democracia racial" (GUIMARÃES, 1988, p.16).

A figura abaixo é sugestiva e remete a permanências da mentalidade daquela época. Trata-se de um texto destinado a alunos do segundo ano. Seu objetivo é celebrar as diferenças e a trajetória de cada um. Nela, os pais discutem o nome que a criança receberá quando nascer. Nesse contexto, tem-se a sugestão da avó para que seja chamado "Miguel Lisboa Júnior”, enfatizando sua herança portuguesa e, dessa forma, aniquilando a possibilidade de sublimar a herança africana. Essa imagem, como se pode vislumbrar, possui elementos próximos ao quadro A Redenção de $\operatorname{Can}^{15}$.

\section{Figura 14 - Embranquecimento positivo}
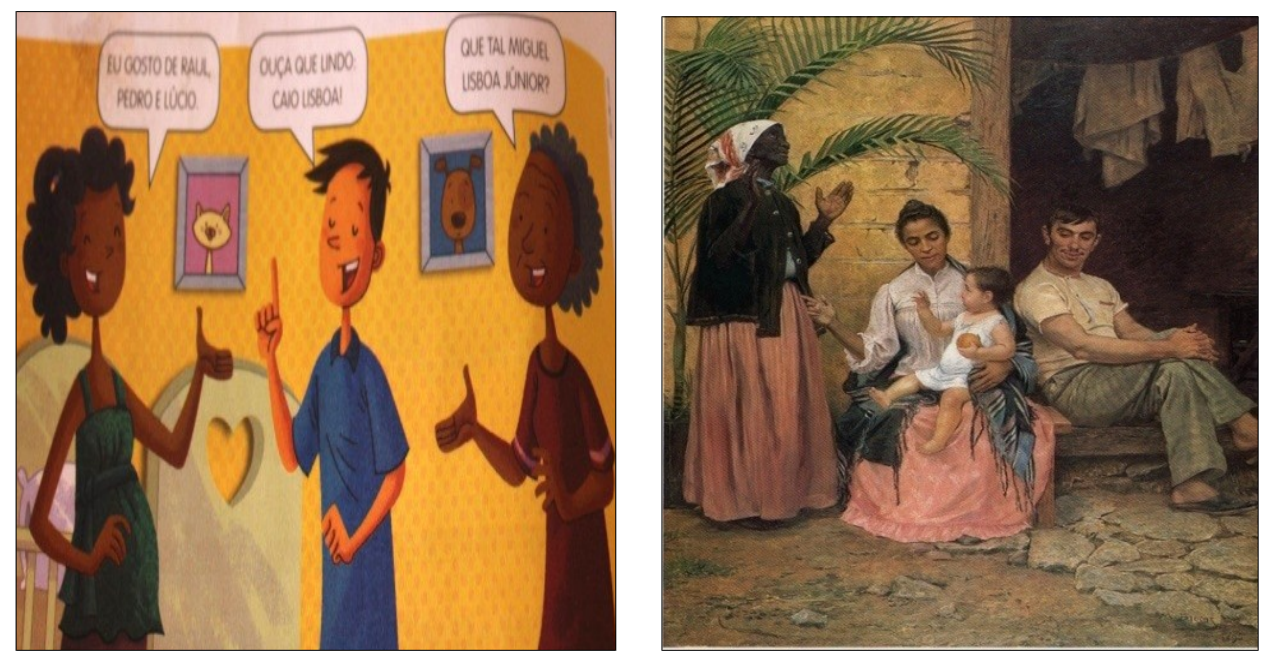

Fontes: História Ligados.com, $2^{\circ}$ ano (2016/2018, p. 10). Disponível em: <http://www.mare.art.br/detalhe.asp? idobra=3097>. Acesso 11 fev. 2017.

Ambas as iconografias reforçam a ideia de um branqueamento positivo, herdeiro do pensamento forjado no IHGB, de que a Nação brasileira se construiria a partir da miscigenação e, consequentemente, do clareamento dela advindo. Nos livros didáticos, são raríssimas as imagens de

$15 \mathrm{O}$ quadro Redenção de Can (1895), do pintor espanhol Modesto Brocos y Gómez (1852-1936), e que pertence ao acervo do Museu Nacional de Belas Artes, serve como retrato da sociedade brasileira miscigenada. Uma das interpretações da obra dá a entender que a avó negra, por intermédio do neto branco, estaria se libertando de uma condição racial que a oprimia. O futuro era branco. A obra de Brocos y Gómez deu margem a uma série de interpretações sobre as "raças" do mundo. A mais decadente delas seria a negra SEYFERTH (2011). Disponível em: $<$ http://www.revistadehistoria.com.br/secao/perspectiva/o-futuro-era-branco >. Acesso: 11 fev. 2017. 
famílias cujo fenótipo negro seja mais acentuado. Como foi dito anteriormente, grosso modo, as famílias representadas são brancas e de classe média.

As imagens, pela simplicidade do cenário e das personagens que protagonizam a cena, parecem perpetuar o mesmo padrão socioeconômico desses indivíduos. Além disso, numa sociedade em que o preconceito racial, em geral, tende a determinar os lugares a ser ocupados pelos indivíduos, também, sugere perspectiva de maior aceitação e ascensão social desses, insinuando-se como a garantia de um futuro melhor para as novas gerações.

\section{4 - Enaltecimento negro: uma fonte de suspeita}

Como já mencionado, nos livros didáticos não há espaço para a representação de heróis, realeza ou divindades negras. As duas imagens abaixo são mais indícios de uma falta do que de uma inserção propriamente dita, pois os espaços que contemplam o padrão de beleza, de realeza e de heroísmo são consagrados aos indivíduos de fenótipo branco e a tudo que acerca a sua cultura.

Figura 15 - O heroico e o divino
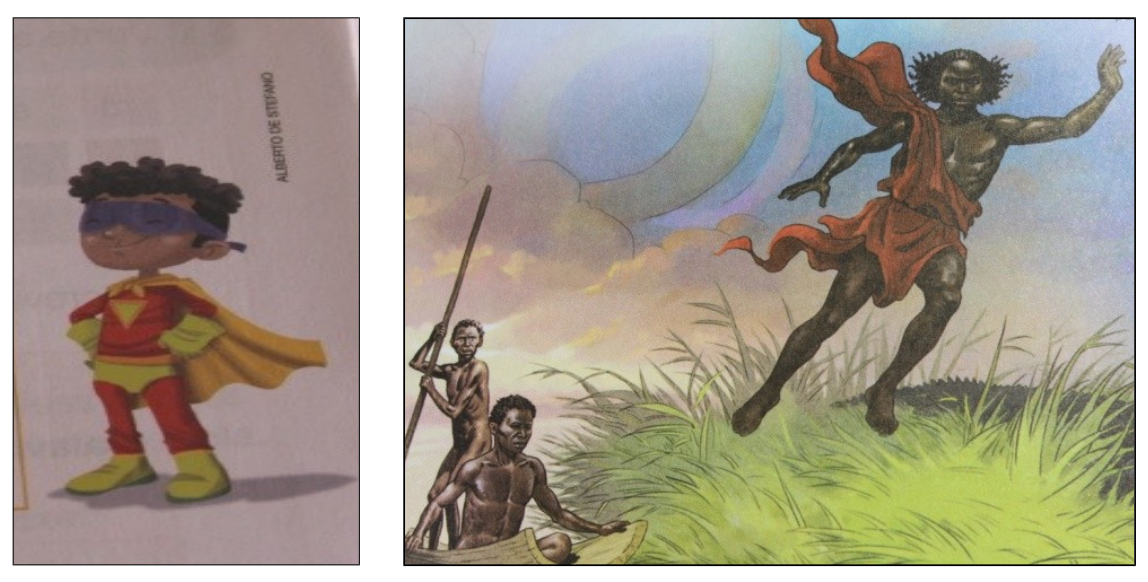

Fontes: Português Projeto Buriti, $3^{\circ}$ ano (2016/2018 p. 175) e Ciências Akpalô, $4^{\circ}$ ano (2016/2018, p. 8).

A criança está representada como um herói ocidental e figura apenas a ilustração numa seção de atividades, ou seja, sem espaço relevante na disposição espacial e gráfica dos livros. Não há heróis negros nos livros didáticos. A imagem à direita é a ilustração do texto "A Origem do Universo", do livro de Ciências Akpalô. Em todos os volumes pesquisados, estes foram os únicos que fizeram essa representação, sendo o arquétipo de herói o consagrado pela sociedade ocidental. 


\section{Figura 16 - $O$ arquétipo de herói}
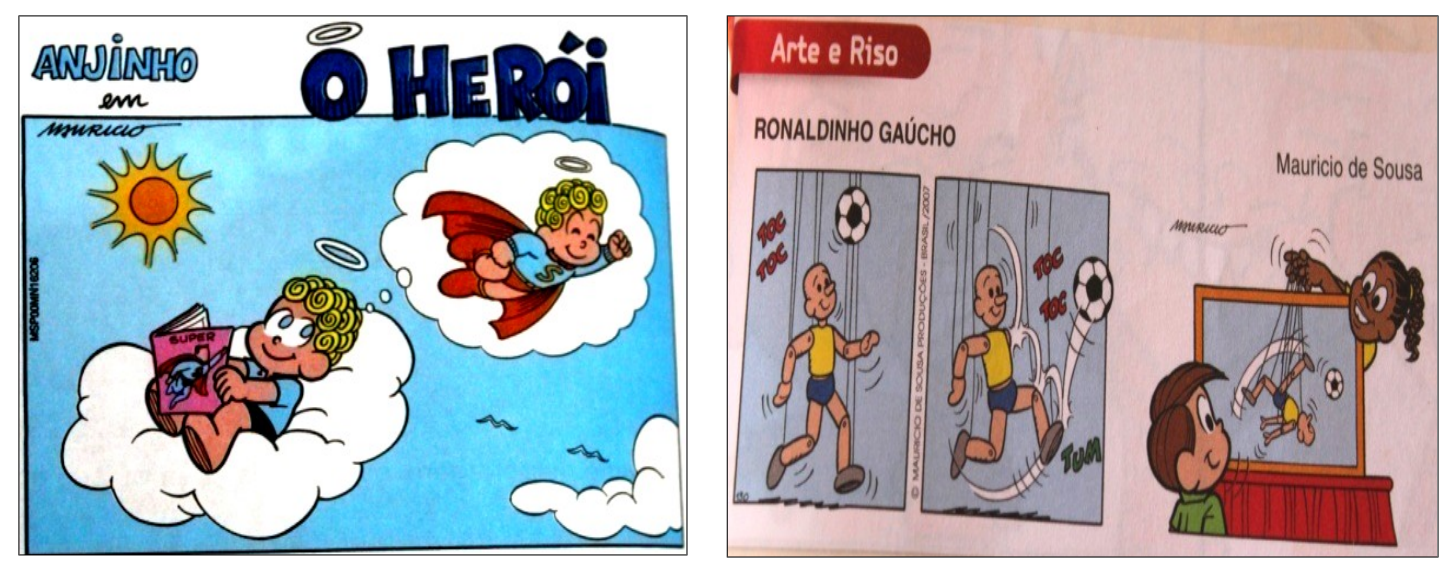

Fontes: Português A Escola é Nossa, $3^{\circ}$ ano (2010/2012, p. 146), Português Projeto Buriti, $5^{\circ}$ ano (2016/2018, p. 87).

Assim, observando os dois personagens acima, tem-se uma ideia do espaço reservado ao herói negro, que tem seu papel restrito ao futebol, à capoeira e às expressões e conhecimentos como culinária, dança e música.

Constroem-se arquétipos de pais, heróis e estudantes - modelos nos quais, muitas vezes, a criança, em particular a afrodescendente, tem dificuldade em se espelhar. Assim, talvez o exemplo que lhe seja mais possível seja aquele cuja aparência física lhe seja mais próximo. Como enfatiza Samuels (1988), os arquétipos são entidades hipotéticas não representáveis em si mesmas. Assim, se exclui uma representação social que sublime a história e cultura africana e da diáspora.

Não obstante, há alguns exemplos interessantes nesse sentido, como na ilustração do texto "O Menino Mais Forte da Rua", de autoria de Pedro Bandeira. Nele, narra-se a história de Zé Pescoço, um garoto branco, grande e forte, que todos os outros temiam na rua. Lula, o menino negro, chegou depois e conquistou a todos. Até que, certo dia, Lula entra em desacordo com Zé Pescoço, mas se sobressai porque usa o diálogo coerente para demonstrar que a luta física não resolveria o problema. Lula é o menino com poder aquisitivo e "adaptado ao meio".

Outra inserção positiva dos negros é demonstrada nas feições afrodescendentes da garota Beatriz, no texto "O Segredo da Vó Maria”, na figura a seguir. 


\section{Figura 17 - Negros sublimados em ilustrações de narrativas}
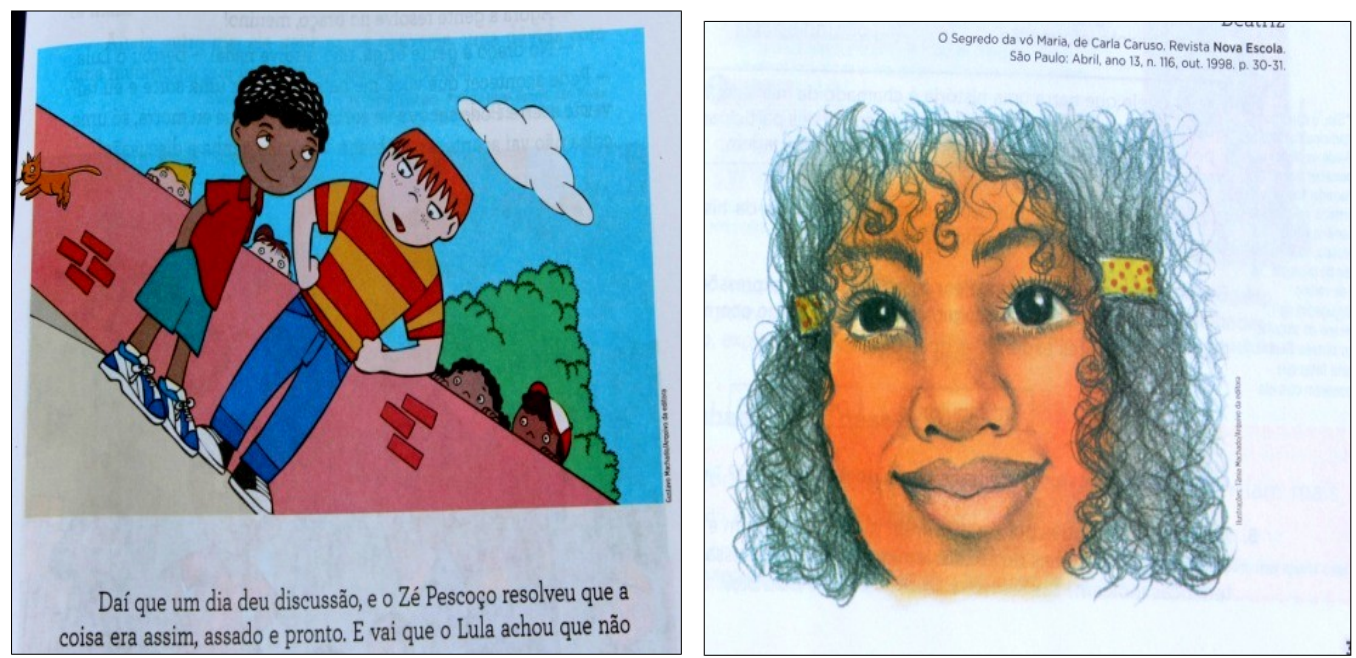

Fonte: Português A Escola é Nossa, $4^{\circ}$ ano (2010/2012, p. 121, 35).

Entrementes os exemplos acima, o notório nos livros didáticos é dedicar lugares secundários, menos proeminentes aos negros, salvo singulares exceções, como no caso da garota Beatriz, que apresenta traços africanos no cabelo, formato do rosto e lábios, sendo a protagonista da narrativa.

\section{Figura 18 - Personagens secundários nas histórias}
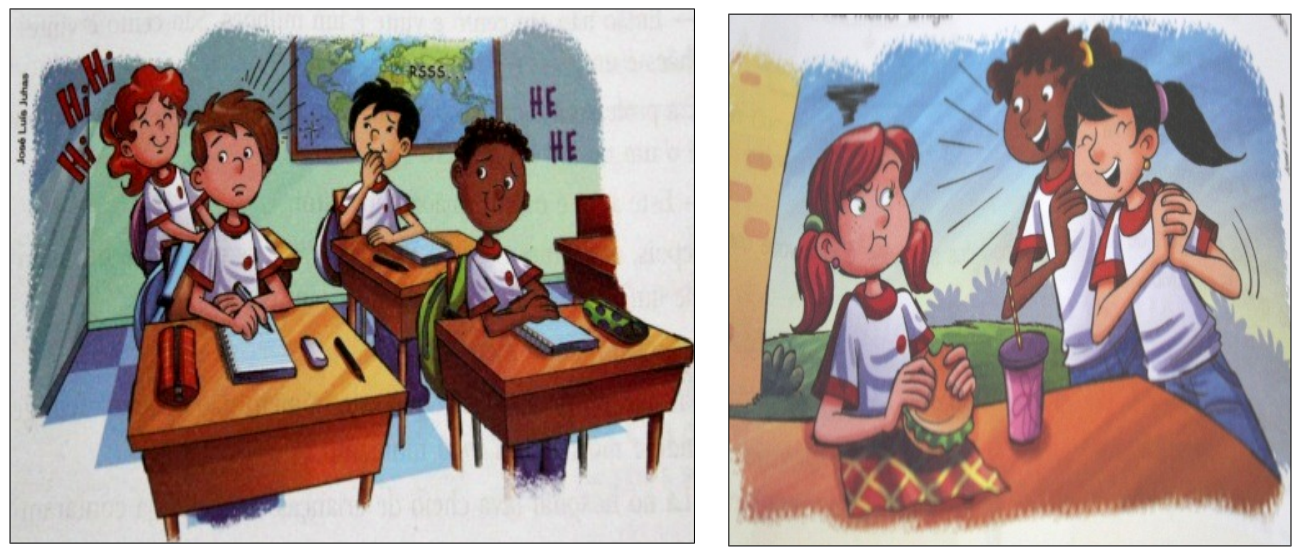

Fontes: Português A Escola é Nossa, $3^{\circ}$ ano (2010/2012, p. 214) e Português Porta Aberta, $5^{\circ}$ ano (2013/2015, p. 202).

Dado interessante é que os manuais, quando fazem uma exceção e protagonizam uma narrativa com personagem negra - que aceita a sua identidade e vê beleza em seus traços físicos identitários, superando a carga de preconceito que envolve todo esse processo -, não fazem jus a uma projeção imagética significativa dessa protagonista no cenário. 


\section{Figura 19 - Protagonistas secundários em imagens}
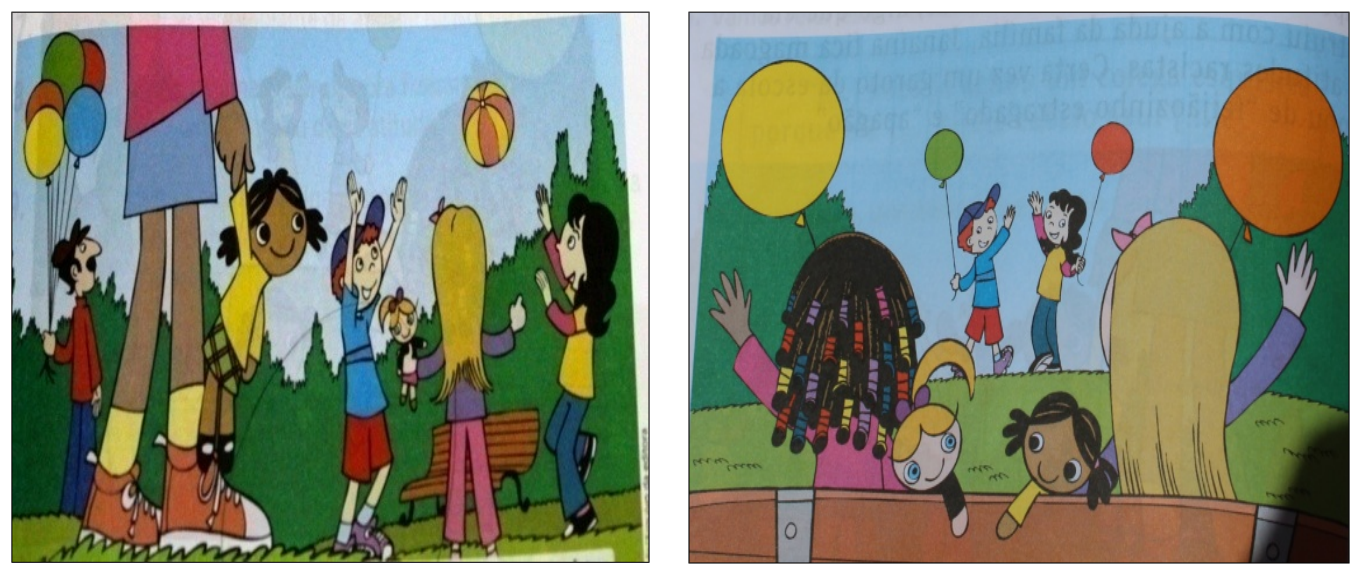

Fonte: Português $A$ Escola é Nossa, $2^{\circ}$ ano $(2010 / 2012$, p. 127,128).

O corriqueiro é exibir o branco, que, além de "heroico" e "esbelto", é o "bom" e, portanto, precisa de uma representação social que demonstre isso continuamente - de fato, os livros o fazem com maestria.

\section{Figura 20 - O branco dita o padrão de beleza}
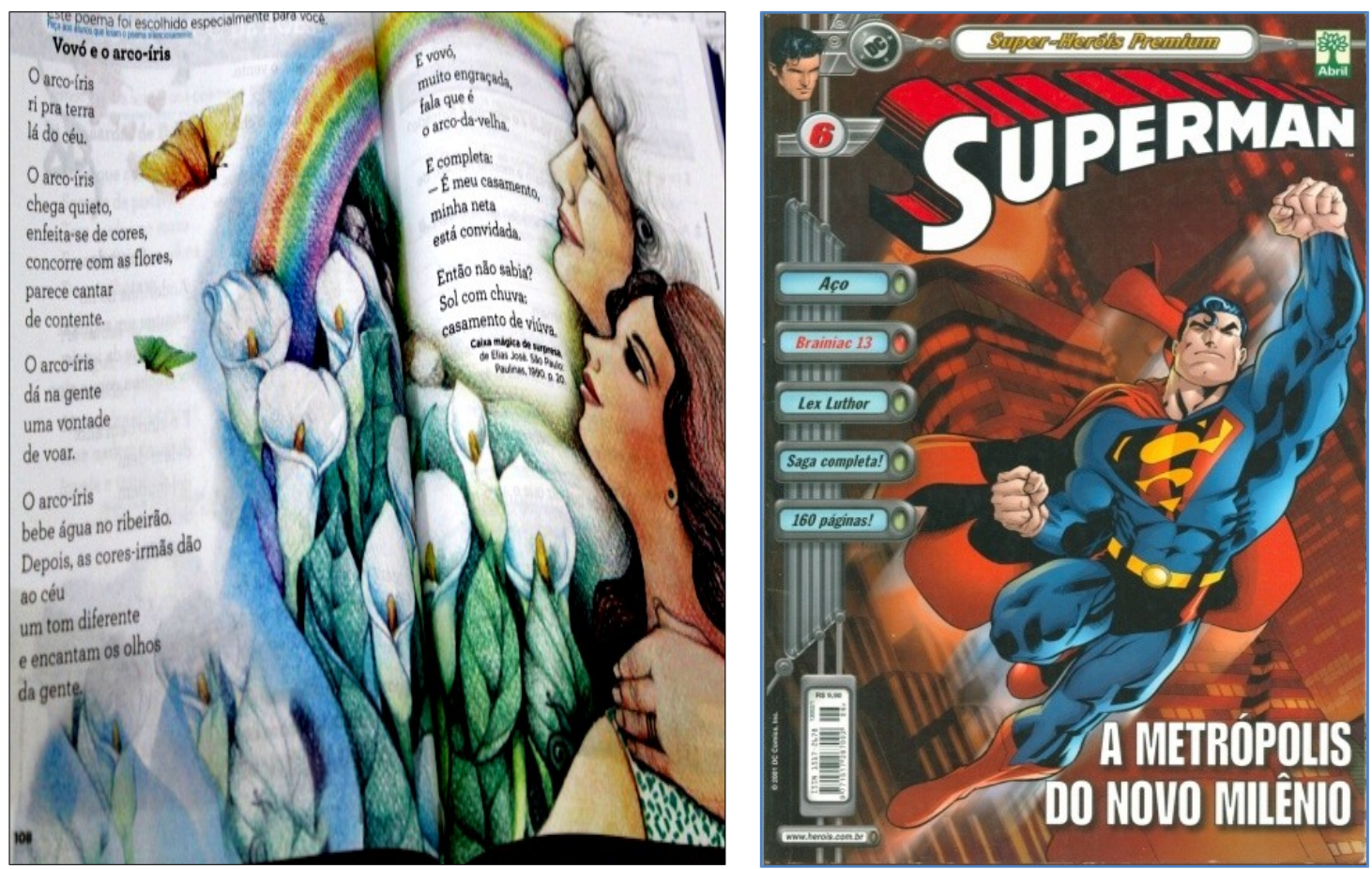

Fonte: Português A Escola é Nossa, $3^{\circ}$ ano (2010/2012, p. 108, 144).

Um contraste com a ilustração acima pode ser exemplificado através da poesia de Castro 
Alves "A Canção do Africano". Aliás, lugar-comum nos manuais são as representações do negro escravizado. Assim, é interessante se questionar o porquê de se trazer assiduamente essas imagens da subjugação e humilhação desses sujeitos para as crianças, reforçando essa memória perversa da escravidão.

O cativeiro de africanos e afrodescendentes no contexto do tráfico atlântico é um dos fenômenos históricos mais complexos da história brasileira e provavelmente global, por isso, não pode ser dispensado de inserção nos conteúdos temáticos das classes de Ensino Fundamental I, principalmente no que diz respeito aos anos finais desse ciclo de ensino.

A contradição talvez resida na ênfase constante da dor, da humilhação, da sobrecarga e do sofrimento transmitidos pela maioria das imagens, em relegar os negros e afrodescendentes a lugares secundários e, dessa maneira, não dar notoriedade às lutas desses sujeitos de forma afirmativa.

\section{Figura 21- Ilustração do texto "A Canção do Africano"}

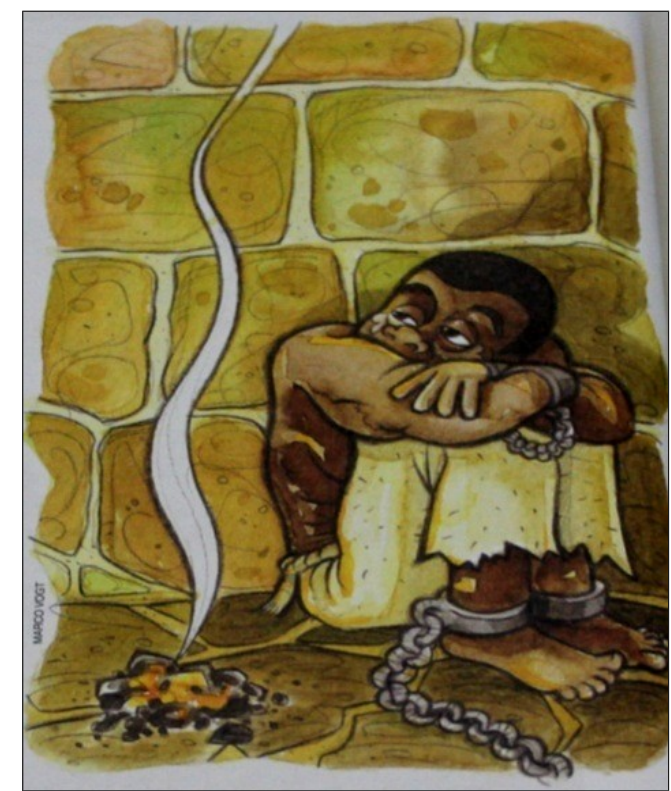

Fonte: Geografia Projeto Buriti, $4^{\circ}$ ano $(2013 / 2015$, p. 121).

Os suportes didáticos que adotam a temática da escravidão em tal perspectiva podem acarretar num reducionismo a esse conceito, como se todos os negros no Brasil colonial e imperial fossem escravos e tivessem, por isso, de andar descalços, com roupas rotas e acorrentados, por desvio de comportamento, como a imagem acima sugere. Além disso, não se acercam de outras modalidades de escravidão para além da atlântica e não enaltecem suas estratégias de engodo a esse 
sistema.

É rara a reprodução imagética de negros libertos, que reconstruíram sua trajetória contrariando a ordem servil. Dessa forma, os livros são modestos em veicular outras efígies desse fenômeno para que o leitor iniciante confronte imagens, narrativas, e construa e desconstrua ideias sobre ele - e, principalmente, que a criança que possua raízes na África, aparentes ou não, critique e não se conforme ou se envergonhe com a experiência cativa vivida por seus antepassados, mas que tenha orgulho dessa trajetória, em especial, das pequenas batalhas cotidianas ou em desfechos heroicos, que possibilitaram a emancipação dos seus antecessores.

Afora essa temática, o livro didático, em geral, se propõe a inserir os negros no campo do exótico e do folclórico. Assim, vão pincelando as sociedades tribais, reforçando a ideia equivocada de que todas as sociedades africanas foram e são, no presente, assim constituídas.

\section{Figura 22 - África e africanos no campo do exótico e do folclórico}

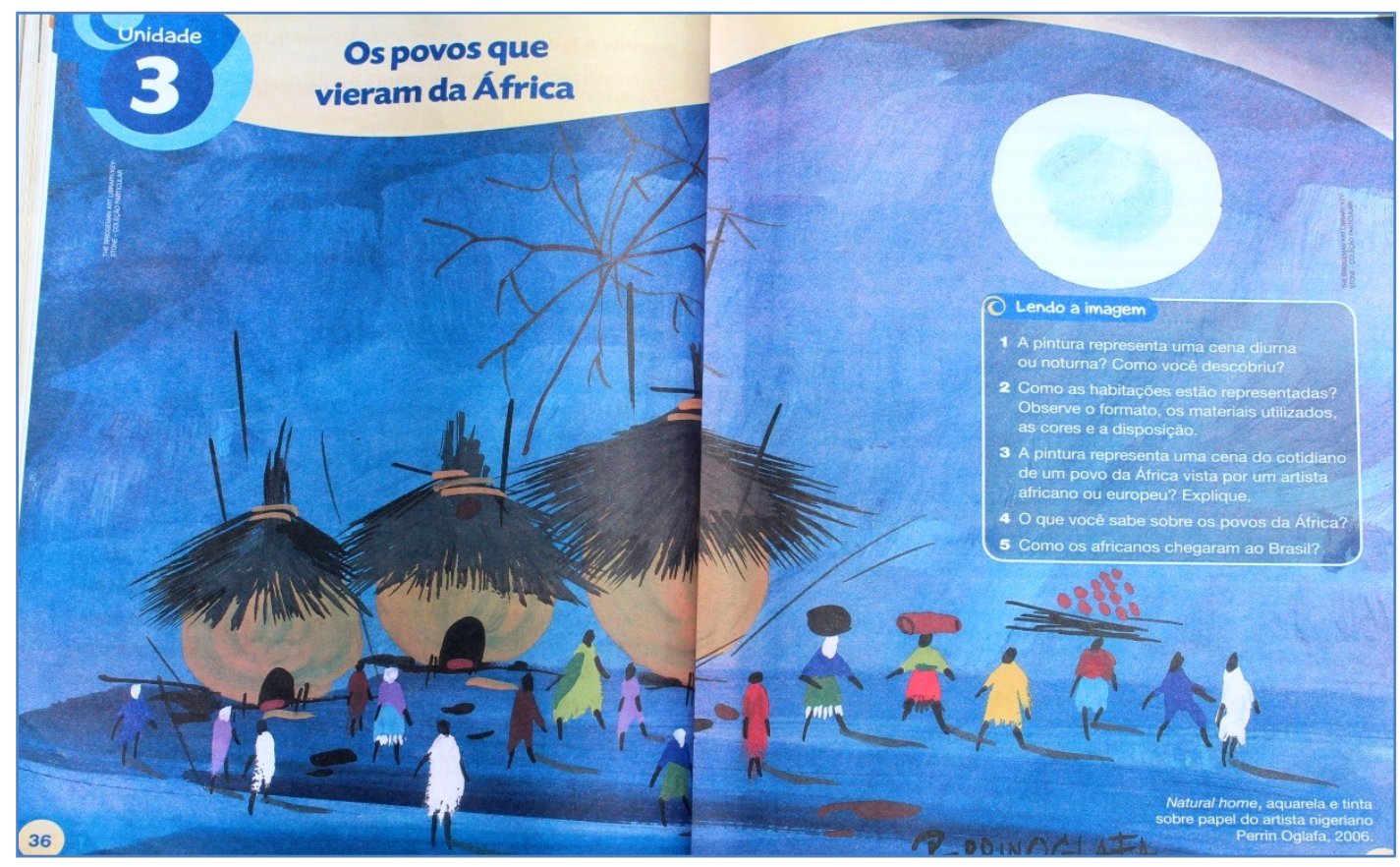

Fonte: História Projeto Buriti, $4^{\circ}$ ano (2013/2015, p. 36)

O próprio título da unidade "Os povos que vieram da África", associado à imagem que a ilustra convergem para que o leitor pense a África tão-somente como uma sociedade tribal, pouco aludindo para outras possibilidades de organização social existentes naquele continente ao longo do processo histórico. 
Os livros demonstram-se ainda eurocêntricos, apresentando imagens, muitas vezes, do negro folclorizado. Há situações em que a mulher é representada de forma erotizada, como na reprodução do quadro Capoeira, de autoria de Zé Cordeiro, encontrada no livro de Português Projeto Buriti, $1^{\circ}$ ano (2016/2018, p. 153). As incidências dessas imagens reforçam as ideias do lugar que o outro deve assumir.

\section{Figura 23 - Folclorização e erotização do corpo negro}

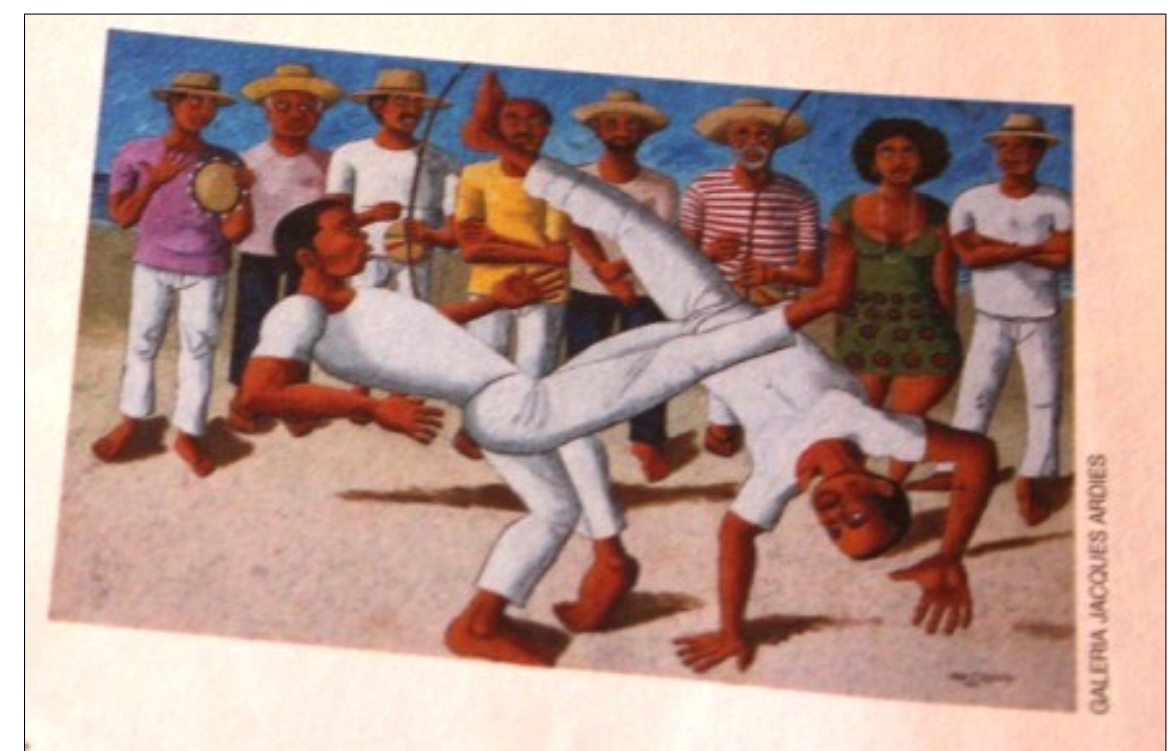

Português Projeto Buriti, $1^{\circ}$ ano (2016/2018, p. 153).

Segundo Linhares (2017), o corpo negro, em particular o da mulher, é submetido a um controle social. Nesse aspecto, possui uma posição ambígua e inferiorizada: ora voltado para o trabalho forçado, ora para o sexo forçado. “Assim, pensar esse corpo, faz primeiramente necessário pensar que lugar o corpo negro ocupa em nossa sociedade.” (LINHARES, 2017).

Dessa forma, o estudante que provavelmente absorve representações sociais estereotipadas da mulher negra em outros veículos de comunicação e expressões artísticas como em novelas, produções cinematográficas e musicais acaba tendo essas ideias reforçadas no ambiente de aprendizagem - nesse caso, através do manual escolar.

O estudo desenvolvido por Nascimento (2015) traz reflexões pertinentes no tocante à erotização do corpo negro no cinema brasileiro, o que expressa práticas e valores flutuantes no meio social, e, portanto, encontra-se multifacetado em diversas instâncias e situações. Dessa forma, não é incomum a representação do negro "nos arquétipos de pretos-velhos, mãe-preta, mártir, malandro, favelado e mulata boazuda, dentre outros”. (Rodrigues, 1988 apud NASCIMENTO, 2015, p. 165). 
Anteriormente, foi ponderado que uma fonte de equívoco dos livros é a não representação das contribuições dos negros para o desenvolvimento da humanidade, principalmente nas primeiras gerações que desenvolveram sistemas de escrita e/ou numeração. De fato, esse uso de imagens de indivíduos brancos pode dificultar a percepção da criança de que a origem da humanidade se deu na África e que, ao que os dados indicam, foram pessoas negras.

Além disso, pode sutilmente produzir a percepção da incapacidade das populações africanas e afrodescendentes em serem protagonistas e pioneiras no desenvolvimento de sistemas de escrita e de outras tecnologias e conhecimentos indispensáveis à sobrevivência da humanidade.

\section{Figura 24 - Primeiros humanos}
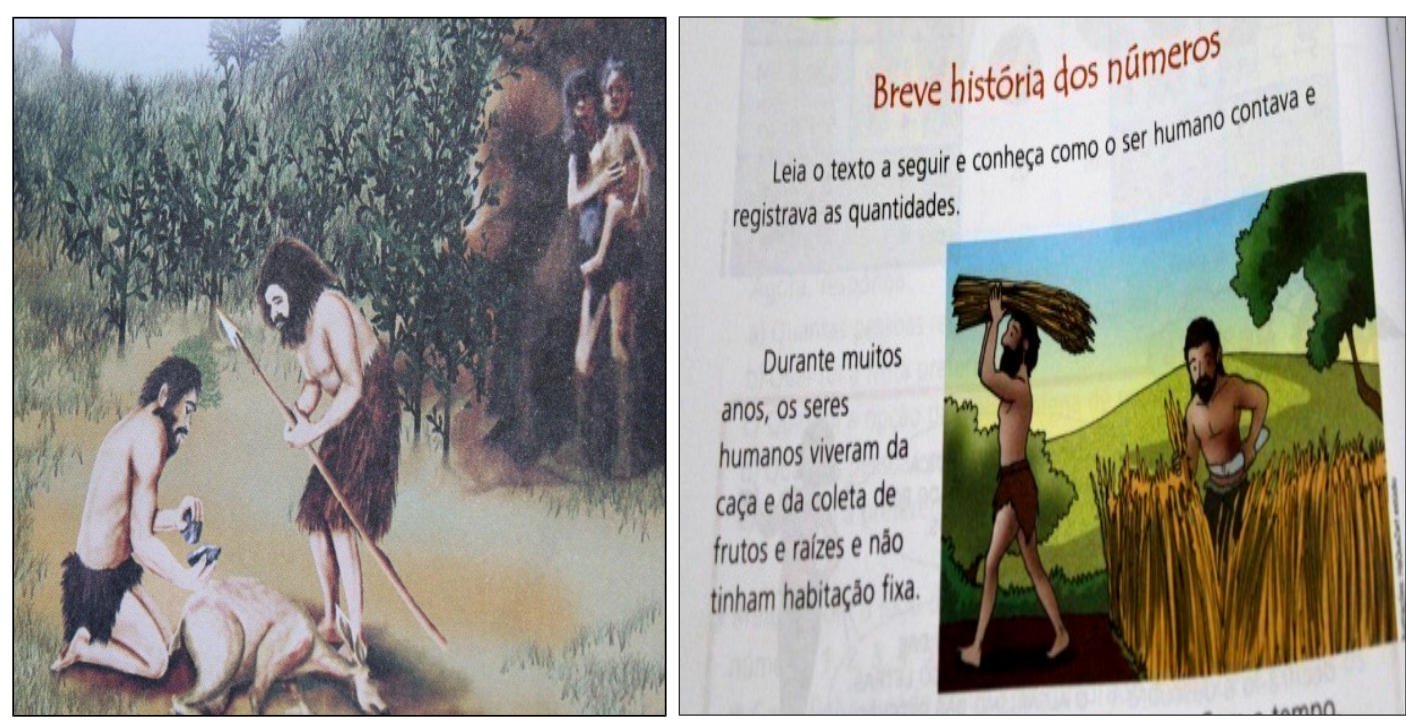

Fontes: História Ligados.com, $3^{\circ}$ ano $\left(2016 / 2018\right.$, p. 8) e Matemática Pode Contar Comigo, $3^{\circ}$ ano (2010/2012, p. 44).

Não obstante, a representação da humanidade original negra foi encontrada em um único livro didático. $\mathrm{Na}$ unidade intitulada "Da África para o Brasil”, do livro História Ligados.com (2016/2018), encontra-se, entre outras, a imagem abaixo, que integra um texto sobre as contribuições dos povos. 


\section{Figura 25 - África, berço da humanidade e do conhecimento}

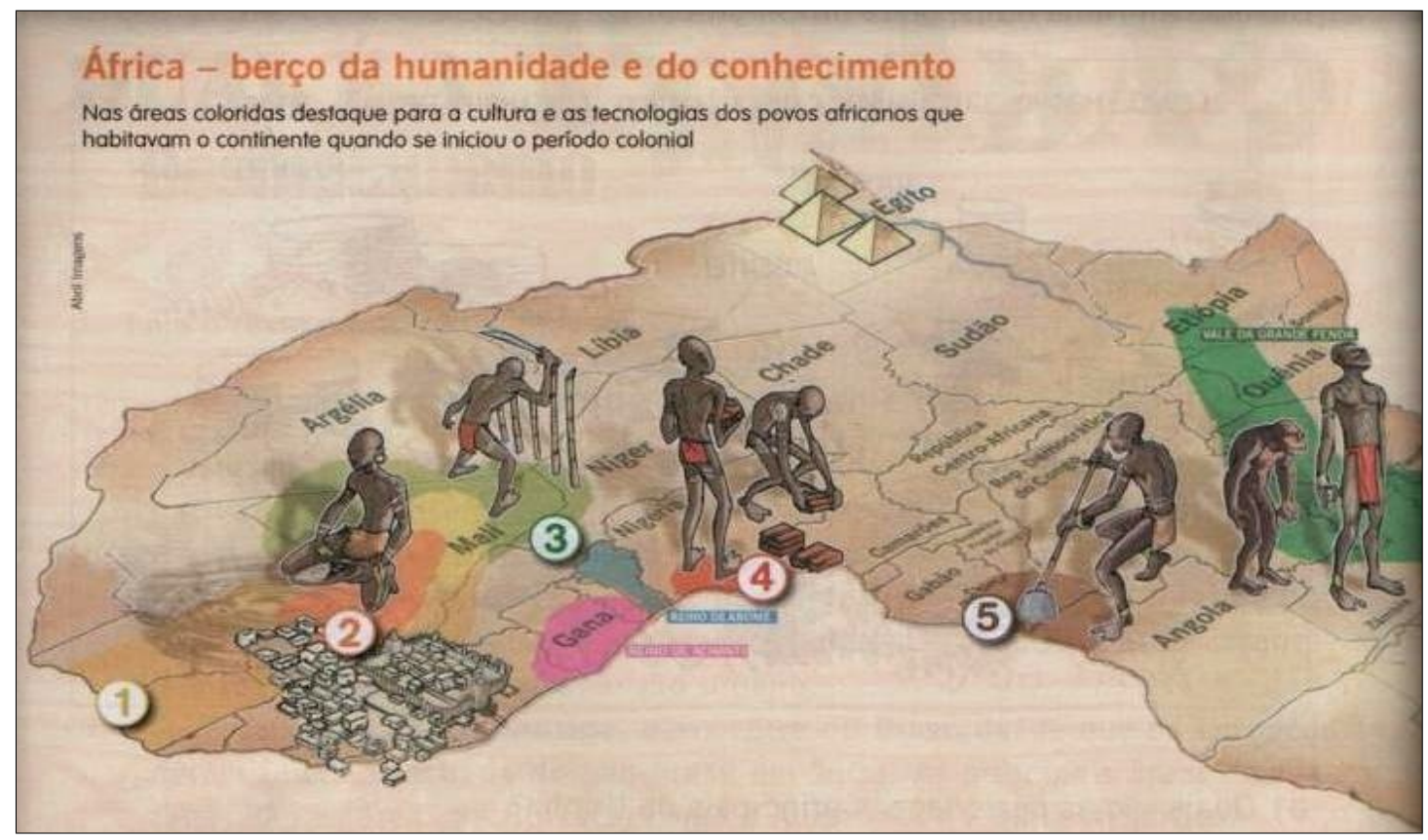

Fonte: História Ligados.com, $4^{\circ}$ ano (2016/2018, p. 74).

Assim, em uma sequência, os negros vão sendo desenhados, executando uma série de técnicas. Note-se, ainda, no canto direito, a inserção de um hominídeo, com características símias acentuadas.

Se não houver um trabalho adequado do professor, uma vez que os livros para esse nível de ensino não tematizam as teorias evolucionistas, são passíveis de cair na ideia equivocada de que o homem é proveniente do macaco, e mais especificamente o negro, podendo reforçar uma imagem depreciativa desses sujeitos sociais, tão fortemente arraigada no chão social, ainda no tempo presente, que nesciamente associa o negro ao macaco. Esse tema, por exemplo, poderia ser já abordado no primeiro capítulo do livro do terceiro ano dessa mesma coleção, intitulado "A Vida na Pré-história", História Ligados.com, $3^{\circ}$ ano $(2016 / 2018$, p. 8).

Dessa maneira, evidencia-se uma sequência de falhas na idealização dos manuais escolares no tocante à abordagem da história da África e dos seus herdeiros. É necessário que essas falhas sejam conhecidas e superadas. 


\section{Considerações Finais}

A análise das imagens, realizada nesta pesquisa, demonstra a necessidade de um cuidado exímio na representação social imagética da África e da diáspora nos manuais didáticos, pois, muitas vezes, perpetuam estigmas que precisam ser abolidos, sejam intencionais ou "acidentais". Ao representar esses sujeitos nos manuais, deveria se levar em conta as "memórias ancoradas em experiências dos que só têm no corpo e em suas formas de comunicação heranças de seus antepassados e marcas de suas histórias”. (ANTONACCI, 2013, p. 17).

Dessa forma, é imprescindível um olhar mais atento para o corpo negro, pois, de fato, tanto quanto as narrativas, as imagens reproduzem situações do contexto social mais amplo, muitas delas contraditórias, como diversas vezes foi possível se observar ao longo deste texto. A imagem pode ser considerada uma das faces da construção da identidade, pois "toda identidade cultural se refere à subjetividade daqueles que querem saber quem são e como se diferenciam dos outros" (RÜSSEN, 2014, p. 26), havendo, como este mesmo autor pondera, a necessidade de uma cultura do reconhecimento, com maior diálogo entre as diferentes tradições, pois a cultura está interligada à busca de sobrevivência dos diferentes grupos humanos.

Diante do exposto, a análise empreendida encontrou respaldo na perspectiva de Moscovici (1978), ao ressaltar que as representações podem ser compreendidas como um conjunto de conceitos, proposições e explicações forjadas na vivência cotidiana das pessoas, bem como na comunicação interindividual, cuja principal função é tornar familiar o não-familiar. Sendo como destaca ainda Techio (2011, p. 9), “a maneira como os grupos sociais constroem e organizam diferentes significados dos estímulos do meio social e as possibilidades de respostas que podem acompanhar esses estímulos". Além disso, são compartilhadas na sociedade - porém, não necessariamente homogêneas.

Dessa forma, ao longo da análise das imagens constantes nesta pesquisa, tendo como aporte a Teoria das Representações Sociais, foi possível identificar alguns dos principais aspectos dela na apropriação e uso das representações sociais. A exemplo da função saber, que possibilita aos indivíduos compreender e explicar determinada realidade; a função de identidade, que garante proteção e especificidade aos grupos, bastante acentuada; a de orientação, com o objetivo de guiar comportamentos; e a justificadora, pois tende a explicar comportamentos e tomadas de posição de grupos e indivíduos em relação aos seus parceiros. 
Nesse caso, os manuais escolares ainda assumem um papel relevante nesse processo, pois, sob o debate de uma educação que contemple a diversidade, muitas representações sociais, mesmo ressignificadas, ainda tendem a enquadrar os negros e afrodescendentes numa situação de não igualdade de condição e oportunidade.

Uma constatação derivada das observações nos livros analisados é a necessidade de seus autores se atentarem para textos e imagens inseridos, pois, muitas vezes, os discursos em textos e imagens se prestam a dubiedades, sendo necessário o estabelecimento de critérios de seletividade em torno do que deve compor os manuais didáticos.

\section{Referências}

ANTONACCI, Maria Antonieta. Memórias Ancoradas em Corpos Negros. São Paulo: Educ, 2013.

APPIAH, Kwame Antony. Na Casa de Meu Pai: a áfrica na filosofia da cultura. Tradução de Vera Ribeiro. $4^{\mathrm{a}}$ ed. Rio de Janeiro: Contraponto, 2014.

BITTENCOURT, Circe Maria Fernandes. Livros didáticos entre textos e imagens. In: BITTENCOURT, Circe (Org.). O Saber Histórico na Sala de Aula. São Paulo: Contexto, 2015.

BURKE, Peter. O que é História Cultural? Tradução de Sergio Goes de Paula. Rio de Janeiro: Zahar, 2008.

CAVAlleIRO, Eliane dos Santos. Do Silêncio do Lar ao Silêncio Escolar: racismo, preconceito e discriminação na Educação Infantil. Universidade de São Paulo - Faculdade de Educação: São Paulo, 1998.

CHARTIER, Roger. A História Cultural: entre práticas e representações. Tradução de Maria Manuela Galhardo. Rio de Janeiro: Editora Bertrand Brasil, 1990.

CRUSOÉ, Nilma Margarida de Castro. A Teoria das Representações Sociais em Moscovici e sua Importância para a Pesquisa em Educação. Aprender - Cad. de Filosofia e Pisc. da Educação Vitória da Conquista, Bahia, Ano II, nº 2, p. 105-114, 2004.

GEERTZ, Clifford. A Interpretação das Culturas. Rio de Janeiro: Zahar, 1973.

GOMES. Nilma Lino. Educação, Identidade Negra e Formação de Professores/as: um olhar sobre o corpo negro e o cabelo crespo. Revista "Educação e Pesquisa", São Paulo, v. 29, n 1, p. 167-182, jan./jun. 2003.

GOMES, Nilma Limo. Educação e Relações Raciais: refletindo sobre algumas estratégias de atuação. In: MUNANGA, Kabemgele (org.) Superando o racismo na escola. Brassília, 
Ministério da Educação, Secretaria de Educação Continuada, Alfabetização e Diversidade, 2005

GUSSO, D. Repetência: a cruel enroscada da repetência: a hora de mudar tudo. Revista Nova Escola. 10 abr. 1998.

GUIMARÃES, Manoel Luis Salgado. Nação e Civilização nos Trópicos: o instituto histórico geográfico brasileiro e o projeto de uma história nacional. Revista "Estudos Históricos", v. 1, n $1,1988$.

LINHARES, Kleiton. O Corpo da Mulher Negra: a dualidade entre o prazer e o trabalho. Disponível em: <http://www.sies.uem.br/trabalhos/2015/623.pdf>. Acesso: 24 mar. 2017.

MACHADO, Laêda Bezerra, ANICETO Rosimere de Almeida. Núcleo Central e Periferia das Representações Sociais de Ciclos de Aprendizagem Entre Professores. Disponível em: $<$ http://www.scielo.br/pdf/ensaio/v18n67/a09v1867.pdf>. Acesso: 3 nov. 2016.

MOSCOVICI, Serge. A Representação Social da Psicanálise. Tradução de Álvaro Cabral. Rio de Janeiro: Zahar, 1978.

. Representações Sociais: investigações em psicologia social. Tradução de Pedrinho A. Guareschi. 11ª ed. Rio de Janeiro: Vozes, 2015.

NASCIMENTO, Jairo Carvalho do. Erotismo e Relações Raciais no Cinema Brasileiro: a pornochanchada em perspectiva histórica. Tese de doutorado. Salvador, 2015.

OLIVA, Anderson Ribeiro. Lições Sobre a África: diálogos entre representações dos africanos no imaginário ocidental e o ensino de História da África no mundo atlântico (1990-2005). Tese de doutorado. Universidade de Brasília, 2007.

OLIVEIRA NETO, Marcolino Gomes de. Entre o grotesco e o risível: O lugar da mulher negra na história em quadrinhos no Brasil. Revista Brasileira de Ciência Política, Brasília, $\mathrm{n}^{\circ} 16$, jan./abr. 2015. Disponível em: <http://dx.doi.org>. Acesso: 13 out. 2015.

RODRIGUES, Elisa. Raça e Controle Social no Pensamento de Nina Rodrigues. Revista Múltiplas Leituras, v. 2, n 2, p. 81-107, jul./dez. 2009.

RÜSEN, Jörn. “Apropriações da tradição - Seguindo Kant: Uma ideia europeia de História universal com propósito intercultural”. In: Id. Cultura faz Sentido: orientações entre o ontem e o amanhã. Trad. Nélio Schneider, Rio de Janeiro: Vozes, 2014.

SAMUELS, Andrew. Dicionário Crítico de Análise Junguiana. Tradução de Pedro Ratis e Silva; Rio de Janeiro: Imago Ed.,1998.

SANTAELlA, Lúcia. O que é Semiótica. São Paulo: Brasiliense, 1983. 